\title{
A new method for ranking academic journals in accounting and finance
}

\author{
Vivien Beattie and Alan Goodacre*
}

March 2006

\begin{abstract}
Given the many and varied uses to which journal rankings are put, interest in ranking journal 'quality' is likely to persist. Unfortunately, existing methods of constructing such rankings all have inherent limitations. This paper proposes a new (complementary) approach, based on submissions to RAE 2001, which is not restricted to a pre-defined journal set and, importantly, is based on quality choice decisions driven by economic incentives. For three metrics, submissions to RAE 2001 are compared with the available set of publications to provide evidence on the perception of journal quality, a fourth metric is based on the overall RAE grades, and an overall ranking is produced.
\end{abstract}

Keywords: journal quality, journal rankings, RAE 2001

* Corresponding author: Alan Goodacre, Department of Accounting and Finance, University of Stirling, Stirling FK9 4LA, UK (e-mail: Alan.Goodacre@stir.ac.uk).

\section{Acknowledgements}

The authors are respectively Professor of Accounting (University of Glasgow) and Professor of Accounting and Finance (University of Stirling). They would like to thank the Faculty of Management, University of Stirling, for the award of a research grant to fund this project and Joanne Lello and Damien Snedden, in particular, for their assistance with data collection. Special thanks go to Elizabeth Davie for her advice and assistance in designing the Access database. The authors also wish to thank the editor, Ken Peasnell and two anonymous reviewers for their helpful and constructive comments on an earlier draft of this paper. 


\section{A new method for ranking academic journals in accounting and finance}

\section{Introduction}

The importance of academic journal articles as a form of scholarly output has resulted in academics devoting a great deal of effort towards the creation of journal rankings. Four approaches to the development of journal rankings have emerged: citation studies, perception studies and, more recently, 'market-test' studies and internet downloading frequency studies. Each of the approaches has limitations. Citation studies depend on the assumption that a citation is an objective indicator of influence. Although most citation studies make use of the Social Sciences Citation Index (SSCI), the number of accounting and finance journals covered by this index is extremely limited, with many major outlets (for non-US academics) not included. Perception studies (also termed peer-review or opinion survey studies) appear to have been the dominant approach used in the accounting discipline. Typically, respondents are asked to assign points to each journal identified by the study, based on its 'value', 'familiarity' and/or 'quality'. However, perception studies may suffer from inherent biases such as a pre-disposition towards journals in which respondents publish. The market-test is based on an analysis of library holdings but may reflect economic circumstances or random factors unrelated to journal quality. The download method suffers from faculty bias in posting working papers.

The objective of this paper is to use the submissions to the most recently completed UK research assessment exercise (RAE) in a novel way to assess relative journal quality. The 2001 RAE required university 'units of assessment' (departments or other groupings of researchers) to identify research-active staff and to submit up to four research outputs for each, as an indicator of the quality of research undertaken. Units of assessment (UoAs) were graded into seven quality bands: $1,2,3 \mathrm{a}, 3 \mathrm{~b}, 4,5$, and $5^{*}$ (for further details see Otley, 2002). As research funding depended on the overall grade awarded, UoAs had significant economic incentives to select what they believed the peer review group (the RAE panel members) would view as the best research.

The working methods of each RAE panel differed slightly, but all the research outputs of accounting and finance researchers were assessed by the Accounting and Finance panel. ${ }^{1}$ The published criteria and working methods of this panel state that, in assessing research quality, it will 'collectively examine in detail at least one cited item per member of staff' (RAE, 1999: §3.35.32). Items not examined were judged, inter alia, on 'evidence of peer review' (RAE, 1999: §3.35.34). The chair of the panel explained that, while 'the current system places considerable reliance, quite properly, on the refereeing processes of academic journals' it is 'hazardous to rely solely on publications in journals deemed to be of high quality as a research assessment tool', as 'the quality of articles within the covers of any single journal can vary considerably in quality' (Otley, 2002: 401). This indicates clearly that the panel itself did not make use of journal rankings. However, to the extent that research quality and journal quality are correlated, economic-related decisions impounded in the RAE submissions can be used to proxy relative journal quality. These rankings, which are proxy measures of the overall rigour and quality of a journal's content and peer review processes, can be used for a variety of purposes. For example, they are useful in guiding author's decisions about where to submit a paper and in benchmarking research productivity for individual promotion decisions and for institutional evaluation purposes. 
The paper contributes by applying methods which improve on prior journal ranking studies in four ways. First, the study ranks journals that are of greater relevance to non-US accounting and finance academics than citation methods which typically deal with a small number of US-based journals. Second, the ranked journals are not constrained to a relatively small pre-determined list of potential journals; the ranked set of journals comprises all those containing papers considered sufficiently meritorious for submission to RAE 2001. Third, the rankings are based on choices which had significant economic implications for those making the decisions, a major advantage over all methods adopted previously in the accounting and finance discipline. Fourth, in contrast to studies which have used RAE 2001 to rank journals in other disciplines, a comparison is made between papers published by the 'research-active' academics during the period and papers that they submitted to RAE 2001. The consideration of papers that were, by implication, judged of 'inferior' quality expands the variability of the available data and thereby improves the potential for discrimination. Finally, and perhaps most importantly, while the methods adopted here have limitations they are different to those present in all other methods that have been used to rank journal quality. Our main contribution can, therefore, be seen as providing triangulation for these alternative methods.

Four metrics are proposed based on the submission choices made in RAE 2001. Using information from research-active individuals' quality decisions, two rankings are based on pairwise comparisons between journals (one at the individual researcher level; the other at the aggregate level). Comparison between publications and submissions underpins the third 'submission to publication ratio' measure. The fourth measure involves the calculation of a weighted average RAE grade (RAE metric) based on the RAE 2001 peer review panel judgements. The three aggregate metrics are combined to produce an overall ranking. Strong correlations are observed between rankings based on the different journal quality proxies and also with recent survey studies. However, a large number of submissions to RAE 2001 were from journals excluded from survey studies, reflecting the diversity of interests of the UK accounting and finance community. Thus, the paper provides a timely analysis of relative journal quality across a wide number of journals of direct relevance to non-US academics.

The remainder of this paper is structured as follows. Section 2 briefly reviews the prior literature on the ranking of accounting and finance journals. The third section sets out the methods applied, focusing particularly on the linkage between the two databases providing the input data. Results are provided in section four, followed by a concluding section discussing the relevance and limitations of the results.

\section{Prior literature}

Given the pre-eminent position of academic journal articles as a form of scholarly output (Parker et al., 1998), it is not surprising that academics have devoted a great deal of effort towards the creation of journal rankings. Two main approaches have emerged based on citation analysis and on peer review perceptions. More recently, two further approaches have been reported based on the analysis of library holdings and on electronic paper downloads via the internet. All approaches have to rely on proxies for the underlying, but unobservable, construct of interest which is journal quality. The number of journals ranked in these studies varies enormously (although it has increased over time as the number of journals has increased). Each of these approaches is outlined below; however, only a brief summary of research using the two main approaches is provided, as there are several good reviews of this literature (e.g., Brown and Gardner, 1985; Hull and Wright, 1990; Brown and Huefner, 1994; and Jones et al., 1996). 
Many citation studies make use of the Social Sciences Citation Index (SSCI). The basic idea is that a citation is an objective indicator of influence. Proponents of this approach argue that it is an objective, value-free, evaluative technique (Brown and Gardner, 1985). However, Jones et al. (1996) suggest three main lines of criticism that have arisen. First, inconsistent rankings have been found, depending on the particular measures adopted. Second, there are 'technical problems' that may obscure the link between citation and quality. An obvious problem is that a citation might be negative, but others are more subtle. For example, authors cite papers that will enhance the likelihood of publication, such as those authored by potential referees and journal editors. Also, citations may be biased in favour of: popular authors who enjoy a 'halo effect'; review papers; methodological papers; or established researchers (Brown and Huefner, 1994). Third, and perhaps most problematically, the number of accounting and finance journals covered by the SSCI is limited, with many major outlets (for non-US academics) not included. Of the 44 accounting and finance journals listed in the most recent UK peer review-based ranking (Brinn et al., 1996), only nine were listed in SSCI. In their study of the finance discipline, Chan et al. (2000) note that just 18 out of the 60 journals in Heck's (1996) Finance Literature Index were included in SSCI. To overcome this limitation, they had to resort to manual collection of citation statistics for their ranking of 59 journals. To provide some context for this limitation, it may be noted that 143 different finance journals were included in respondents' lists of 'top 20' journals in Oltheten et al. (2005). Similarly, UK accounting and finance academics published in 126 different accounting and finance academic journals in the two year period 1998-9 (Beattie and Goodacre, 2004) but only 21 of these journals (17\%) are abstracted in the SSCI.

Perception studies typically ask respondents to rank a provided list of journals based on 'value', 'familiarity' and/or 'quality'. Of the two recent UK studies one evaluates 44 accounting and finance journals (Brinn et al., 1996) and the other 32 accounting journals (Lowe and Locke, 2005). A recent international study investigates the ranking of 58 named journals (Ballas and Theoharakis, 2003). Such studies typically overcome many of the limitations of citation studies but suffer from their own limitations related to the use of survey methods. In particular, they suffer from 'technical problems' such as non-response bias (responses from non-respondents may differ from those obtained), sample representation bias (the sampled groups may not be representative of the entire population), and position bias (journal placement in the survey questionnaire may bias responses) (Brown and Huefner, 1994). Responses may also suffer from self-serving predisposition bias towards different journals, particularly those in which the respondent either publishes or acts as reviewer/editor. Importantly, such studies are necessarily subjective as they rely on human judgement.

The market-test is based on an analysis of library holdings. Bertin et al. (1994) rank 62 journals using the holdings of 264 schools. Zeff (1996) reports on subscriptions to 67 accounting journals by twelve major libraries (located in the US, the UK and Australia), identifying three modal groups across the grading of journals. These gradings are interpreted as quality rankings by Wilkinson and Durden (1998) and Durden et al. (1999) and used by them to construct weighted measures of productivity of accounting faculty in New Zealand and Australia, respectively. Locke and Lowe (2002) replicate Zeff's analysis for all 46 universities in Australia and New Zealand, with the intention of constructing a set of journal rankings of relevance to authors from that region; they find a 'good deal of disparity' between their results and Zeff's journal gradings.

The advent of electronic versions of papers available for downloading from the internet provides another avenue for assessing journal quality. Two early illustrations of the potential of this approach use the download frequency of heavily downloaded working 
papers from the Social Science Research Network (SSRN). The first ranks the journals in which the papers were subsequently published (Brown, 2003), while the second ranks PhD programmes and faculties (Brown and Laksmana, 2003). The download frequency is used to provide the measure of 'impact', and by inference a measure of journal and or facultymember 'quality'. Brown identifies three advantages of such an approach. It is demanddriven at the micro-level, it potentially includes any/all journals that faculty might publish in, and it allows the academic community to register their views before the gatekeepers (editors and reviewers) decide what should be published. Limitations of the procedure are that downloaded papers may not actually be read, low quality papers by popular authors, or papers on hot topics may be more heavily downloaded, and authors can bias the measure by frequently downloading their own papers. Another issue identified by Brown (2003) is that there is a faculty bias in posting working papers, with financial faculty more likely to post their working papers to SSRN. However, the procedure appears to produce similar rankings to other studies and download frequencies are found to be positively related to citation frequencies.

While many journal ranking studies appear content to treat the measures obtained (using any approach) unproblematically as interval level measures, some writers have chosen instead to classify the measures into broad ordinal categories. Gray and Helliar (1994) establish two journal groups based on refereeing policy: premier journals (of which there were 40) which are always refereed, and secondary journals (of which there were 39) which are predominantly academic but not always refereed or where the refereeing policy is unclear. Brown and Huefner (1994), in a perceptions study of 44 accounting journals using US respondents, refer to 'three thresholds of quality'. Zeff (1996) identifies three modal groupings from his study of library holdings. Hickman and Shrader (2000) create three quality groupings out of the 71 finance journals listed in Heck's Finance Literature Index, making use of Alexander and Mabry's (1994) citation-based quality ratings. Hasselback et al. (2000) create four groups in their study of productivity benchmarks for accounting faculty by using cluster analysis: the best 4, the best 12, the best 22 and the best 40. This ordinal grouping approach has the advantage of not suggesting spurious accuracy in the ranking measures although inevitably a boundary problem exists for those journals at the margins.

Prior research using different methods over quite a long time period has identified a very small number of top journals with remarkable consistency. However, the quality of the large number of remaining journals, those in which most research by most academics is likely to be published, is not well-determined. In part, this might reflect variable research quality within each particular journal, variations over time, or perhaps local factors within different geographic regions. However, it also reflects the difficulty that researchers experience in assessing quality using the approaches outlined above. The current research contributes by adopting a novel approach that has advantages over prior methods. Specifically, the approach is not constrained to a limited pre-identified set of journals and is informed by economic incentives.

\section{Methods}

Members of the UK accounting and finance academic community are based either in departments within traditional faculties (or schools), often representing a loose grouping of management-type disciplines, or within more integrated business schools. Universities were able to choose whether to include research-active staff from the community within the specific 'Accounting and Finance' (hereafter A\&F) unit of assessment or within the broader, and larger, 'Business and Management' (hereafter B\&M) unit of assessment. If included within $\mathrm{B} \& \mathrm{M}$, accounting and finance researchers were cross-referred to the $\mathrm{A} \& \mathrm{~F}$ 
panel for advice to improve the consistency of quality assessment (Otley, 2002). Universities were free to identify which of their staff should be submitted as researchactive, such staff contributed to the RAE grade achieved and attracted (to the university) the research funding which was allocated on the basis of RAE 2001. Staff which universities identified as non-research-active were excluded from the RAE ranking process and attracted no research funds. ${ }^{2}$

Each research-active member of staff was allowed to submit up to four publications for quality assessment by the peer review panel; the census period for publications covered the five complete calendar years 1996 through 2000. The restricted population of researchactive staff and their four 'best' publications were identified from the RA2 submissions made to the two relevant panels of peer-reviewers (A\&F, and $B \& M)$, available from the RAE 2001 web-site (RAE, 2001). The full population of publications available for submission in the census period was identified from the three relevant biennial British Accounting Review Research Registers (Helliar and Gray, 1998, 2000; Helliar et al., 2002). ${ }^{3}$ Staff from the accounting and finance community (defined as those included in at least one of the three registers) were matched with those submitted to RAE 2001 as research-active, thereby screening out of the community those defined (in RAE terms) as non-research-active.

Although the total number of articles from a particular journal that was submitted to RAE 2001 is interesting in its own right and is reported in the present paper, this measure gives a poor indication of perceived quality. Some journals, particularly US-based ones, are not easily accessible to UK academics for reasons unrelated to journal quality. A stronger indication of quality can be obtained from the comparative choices actually made, by comparing the submitted subset in relation to the available set of publications. This comparison can be made at two levels, the individual staff member level and the aggregate population of submitted staff.

\section{Metric 1: Individual pairwise comparisons}

First, at the individual staff member level, a procedure to capture the micro 'quality' decision-making process was adopted. For this, a large number of pairwise comparisons was made to identify how often a paper in a given journal was chosen in preference to papers in other journals, with the preferred paper implied to be of higher quality. For example, if a paper from journal A is submitted to RAE 2001 by a particular researcher but one from journal $\mathrm{B}$ is not, the implication, ceteris paribus, is that $\mathrm{A}$ is perceived as a higher quality piece of work; this suggests that journal A is of higher quality. In later reported results, this is termed a 'win' for journal A and a 'loss' for journal B. If an individual researcher has 6 items available for submission (i.e. 4 selected and 2 not), then differential quality inferences can be made in relation to 8 pairwise comparisons (it is not possible to distinguish between the 4 selected items). Such pairwise comparisons provide, for each researcher and then in aggregate, a tally of the number of times a particular journal is preferred (wins) over each of the other (non-submitted) journals.

This information can be used to produce a ranking of journals using the transitivity principle; i.e. if journal $\mathrm{A}>\mathrm{B}$ and journal $\mathrm{B}>\mathrm{C}$, this implies journal A > C. Detailed analysis of this type can be used to construct a rank order of journals. Specifically, a summary matrix of pairwise comparisons was produced and then refined manually by changing the rank order iteratively to minimise the number of inconsistent cells (win/loss reversals) in the table; these inconsistencies indicate situations where the transitivity principle breaks down. Inconsistencies close to the diagonal were removed first as these removals were less likely to create further inconsistencies. Changing those further from the diagonal typically produced more inconsistencies than were resolved. While it is 
impossible to eradicate all inconsistencies, the ranking is likely to be a good approximation based on the relatively noisy data (see also footnote 14). An advantage of the approach adopted is that the ranking avoids the use of other metrics used in the present paper, so can be viewed as having a degree of independence. Conceptually, the approach is perhaps the strongest of those used. However, in practice there were only a small number of pairwise comparisons available for many journals, so the method had to be restricted to a relatively small set of journals. While these were the more 'popular' and, therefore, also important journals as far as the UK accounting and finance community is concerned, other metrics with wider applicability were also used.

\section{Metric 2: Aggregate pairwise comparisons}

The second method, while still based on pairwise comparisons, avoids the difficulty with the first method by combining the comparisons into an aggregate measure. An overall preference ratio based on the total number of wins and losses for papers from each journal was calculated:

Preference ratio $=\frac{\text { no of wins }}{\text { total no of comparisons }}=\frac{\text { no of wins }}{\text { no of wins }+ \text { no of losses }}$

This aggregate preference ratio gives an overall indication of the accounting and finance community's views about the relative quality of papers in each journal. A high preference ratio suggests that the journal is clearly favoured by the community. A limitation of this metric is that no distinction is made between wins over high or low quality journals; each win (or loss) is ranked equally.

The two metrics presented thus far involve a comparison between each researcher's available publications and those submitted to RAE 2001. It should be recognised that both of these metrics are unable to take into account various 'game playing' strategies that might have been adopted by individual UoAs. ${ }^{4}$ For example, suppose that researcher A had several high quality papers jointly authored with less experienced staff. The UoA had to decide the optimal allocation of the jointly-authored papers between the co-authors. Given that the A\&F panel had indicated in its published working methods that it did not expect the same paper to be submitted more than once by the same UoA, the UoA might have considered it optimal to 'allocate' one or more of the papers to a less-experienced researcher (B) to boost his/her profile of publications. This might have enabled extra researchers to be included as research-active or might have contributed to an overall increase in the ranking achieved by the UoA, resulting in positive economic consequences in both cases.

The effect of this rational behaviour is to introduce a limitation to the present study. The observation related to researcher A is adversely affected, in that the 'allocated' high quality publication will be deemed inferior to those (from other journals) actually submitted by researcher A. Given that it is not possible to adjust for this within the research design, it is important to consider the likely impact of this limitation. Assuming that the effect is random across high quality journals, the impact will be neutral across these journals though some noise will be introduced. Nonetheless, it will serve to reduce the differences observed between high quality and lower quality journals, in effect a form of symmetric 'mean-reversion'. However, there is no reason to expect that any systematic asymmetric bias will be introduced to the rankings. It is important to note that the remaining two metrics do not suffer from this limitation. 


\section{Metric 3: Aggregate submission to publication ratio}

Third, based on aggregate rather than individual staff level comparisons, comparative choice was measured by calculating the percentage of the entire set of publications by research-active staff in a particular journal that was actually submitted to RAE $2001 .^{5} \mathrm{~A}$ journal for which a higher percentage of the available publications was submitted implies a perception of higher quality. For this metric, 'allocation' of a paper to a joint author has no impact as the paper is included in the 'submitted' count for the journal.

\section{Metric 4: Weighted average RAE grade (RAE metric)}

A fourth ranking metric was based on the overall RAE 2001 grades awarded to UoAs. These were used to calculate a weighted average grade (RAE metric) of UoAs submitting papers from each journal. ${ }^{6}$ A journal with relatively more submissions by higher rated UoAs suggests higher quality papers therein, so a higher quality journal. The metric is defined as:

RAE metric $_{\mathrm{j}}=\frac{\sum_{\mathrm{i}=1}^{7} \mathrm{sub}_{\mathrm{ij}} \times \text { RAE grade }_{\mathrm{i}}}{\sum \mathrm{sub}_{\mathrm{ij}}}$

where:

$\operatorname{sub}_{\mathrm{ij}}=$ total number of submissions from journal $\mathrm{j}$ to RAE 2001 for UoAs with transformed grade: RAE grade ${ }_{i}$

RAE grade $_{i}=$ transformed UoA RAE 2001 grade ranging from $\mathrm{i}=1-7$ (i.e. ranks $1-5^{*}$ )

For example, there were 64 submissions from Accounting and Business Research to RAE $2001\left(\sum \mathrm{sub}_{\mathrm{ij}}=64\right)$. Of these, the number of submissions from UoAs graded 1 through 7 were, respectively, $0,0,2,2,7,37,16$ (see row 2, Table 2, later). Thus, the weighted average RAE grade (RAE metric) of UoAs submitting papers from the journal equals 6.0, calculated as:

$\operatorname{RAE}$ metric $=\frac{(0 \times 1)+(0 \times 2)+(2 \times 3)+(2 \times 4)+(7 \times 5)+(37 \times 6)+(16 \times 7)}{64}=\frac{383}{64}$

For this metric, the research quality difference between adjacent RAE grades is implicitly assumed, somewhat arbitrarily, to be equal. This was not the view taken by the funding bodies when allocating research funds to UoAs on the basis of RAE 2001. For departments in England and Wales, the Higher Education Funding Council awarded research funds according to the ratios 2.707: 1.89: 1: 0.305 for UoAs graded 5*, 5, 4 and 3a (transformed ranks 7, 6, 5, 4) respectively with no funds awarded to those graded $3 \mathrm{~b}, 2$ or 1 (transformed ranks 3, 2 ,1) (p. 415, Otley, 2002). ${ }^{7}$ Consequently, a second ranking metric was investigated, similar to RAE metric, in which greater weight was given to papers from more highly ranked UoAs reflecting the relative 'worth' attached to the research used by funders in allocating research funds. This could be viewed as somewhat similar to the 'money-weighted return' measure in financial management. However, the ranking using this second metric was almost identical to that obtained using RAE metric (Spearman correlation $=0.992)$ so is not separately reported.

To ensure that there are at least a moderate number of data points on which to base inferences, only journals with a combined total of five or more submissions to A\&F and B\&M panels in RAE 2001 are analysed and reported for metrics 2 through $4 .^{8}$ The RAE metric is reported based on submissions to each panel separately and combined, with the combined score used to rank the journals. The merging of the RAE grades produced by the separate panels into a single combined measure is not without problem. First, the grade awarded by the B\&M panel related to a relatively large and diverse group of constituents 
reflected in the typical business school. Thus the link to the contribution by members of the accounting and finance community is less strong than for submissions to the $A \& F$ panel. Second, the average grade awarded by the two panels differed. For example, for the 63 journals in Tables 4-7, the mean RAE grade (metric 4) is 5.98 for the A\&F panel, 5.37 for B\&M and 5.62 overall. However, this should not, in itself, affect the combination as long as the relative ranking of journals is similar across the two panels. For metric 4, the rank correlation between the A\&F panel and the overall rank used in Table 6 is high. For example, for all journals with at least 2 submissions to the A\&F panel $(n=43)$ the correlation is 0.81 and for journals with at least 3 submissions $(n=27)$ it is 0.91 . Thus, there is good evidence to suggest that the combination of panels is not introducing significant bias into the rankings.

Third, there is an implicit assumption that all work in a (say) 5-rated department is of the same high standard. This is clearly not the case, as the criterion for awarding a 5 was between $10-50 \%$ of the work submitted should be of 'international' quality, so a significant proportion of the research output was of lower quality. Again, it can be argued that this will introduce noise, rather than bias, to the results. ${ }^{9}$

Finally, to summarise the overall picture emerging for the common set of journals from the use of the three aggregate metrics, an overall rank is computed based on the simple mean of the ranks from the three. Each of the three proxies has different advantages and limitations and none of them is clearly dominant, so the use of a simple mean rank, while somewhat arbitrary, does not seem unreasonable.

\section{Results}

\section{Background statistics}

Table 1 provides summary statistics about research-active staff submitted to either the $A \& F$ or B\&M peer-review panel of RAE 2001. It reports the number of staff and the number of outputs submitted, analysed by the ranking obtained in the RAE ( 1 to $5^{*}$, transformed into rank 1-7) and the type of output.

\section{< Table 1 about here>}

Panel A shows that publications for 2,925 research-active staff were included in 117 institution submissions; 8,652 items of output were journal papers and 2,101 were other forms of output such as book chapters, discussion papers etc. Panel B repeats this information for the subset of staff from the 'accounting and finance community' as defined by entry in at least one of the three relevant Research Registers. Thus 525 of the total 2,925 research-active staff, from 79 different institution submissions, ${ }^{10}$ were listed in at least one of the registers, and 1,577 academic journal papers were submitted for these staff. $^{11}$

\section{Submission statistics by journal}

Table 2 reports the frequency with which papers from each journal were submitted by research-active staff from the accounting and finance community to RAE 2001, analysed by RAE grade. Panel A shows the 30 (including ties) most frequently submitted journals, ordered by total number of submissions. Panel B shows the distribution of submission numbers across all submitted journals. As might be expected, the submission numbers are negatively skewed with a large tail of single submissions (217 journals). The number of journals comprising $50 \%$ of the submissions is 26 overall, but with greater concentration in the A\&F panel (17 journals) than the B\&M panel (29 journals). As might be expected from our focus on the accounting and finance community, the journals most frequently 
submitted to the two panels were generally very similar, with 9 of the top ten common to both panels, albeit with different proportions of submissions.

$<$ Table 2 about here $>$

The data in Table 2 provide an initial opportunity to identify which journals appear to be highly regarded by high ranking research UoAs. For example, six journals achieve ten or more submissions by rank $7\left(5^{*}\right)$ departments: Journal of Business Finance and Accounting, Accounting and Business Research, Accounting Organizations and Society, Journal of Banking and Finance, Journal of Finance and Research in Financial Studies.

Metric 1: Individual pairwise comparisons

A journal which published a paper that was not submitted by a research-active individual to RAE 2001 can, ceteris paribus, be inferred to be of lesser quality than the journals which published the papers that he/she did submit. For each pair of journals in this comparison, one wins (submitted paper) and one loses (not submitted). Table 3 summarises the results of this comparison for 18 of the 19 most frequently submitted journals $^{12}$ in a matrix indicating the number of wins and losses for each pairwise comparison. For example, the intersection of the British Accounting Review row and Journal of Business Finance and Accounting column shows 21 wins for Journal of Business Finance and Accounting over British Accounting Review and 8 losses. Overall, papers in Journal of Business Finance and Accounting were perceived as of higher quality than papers in British Accounting Review by those submitting to RAE 2001. A blank win/loss cell (e.g. Accounting Organizations and Society/Applied Financial Economics) implies that no direct comparison between the journals is possible since no researcher submitted a paper from either journal to RAE 2001 and also had published papers in the other journal available for submission. However, the transitivity principle was used to produce a ranking of journals where no direct comparison exists. For example, since Accounting Organizations and Society is preferred to Journal of Business Finance and Accounting (4 wins 0 losses) and Journal of Business Finance and Accounting is preferred to Applied Financial Economics (15 wins 2 losses), Accounting Organizations and Society can be inferred as superior to Applied Financial Economics.

After an initial ranking of journals, a summary matrix in the style of Table 3 was produced. Reading down each column, cells below the diagonal should show net wins for the column journal since the column journal is ranked higher than the row journals; conversely, cells above the diagonal should show net losses for the column journal. The ranking was then refined manually by trial and error to minimise the number of inconsistent cells (win/loss reversals) in the table. For example the comparison between Financial Accountability and Management and Accounting and Business Research shows 4 wins and 0 losses for Financial Accountability and Management, suggesting that Financial Accountability and Management should rank higher than Accounting and Business Research. However, placing Financial Accountability and Management above Accounting and Business Research violates the implied superiority of 5 journals (Accounting, Auditing and Accountability Journal, Journal of Business Finance and Accounting, Critical Perspectives on Accounting, Accounting, Business and Financial History and Management Accounting Research) over Financial Accountability and Management; i.e. solving 1 inconsistency produces 5 more! ${ }^{13}$ While some such inconsistencies remain in Table 3 (win/loss reversals indicated by shaded cells ${ }^{14}$ ), and the solution may not be unique, the ranking is consistent with alternative determinations. ${ }^{15}$

< Table 3 about here> 
The next three tables summarise the rankings of a much larger set of 63 journals (i.e., those with at least 5 submissions to RAE 2001) using three different metrics. Papers submitted to RAE 2001 from these 63 journals comprise 1,032 (65\%) of the total 1,577 journal paper submissions. The inclusion of more journals in the ranking set increases the potential relevance of the analysis but at the cost of reduced reliability. Caution needs to be exercised in attributing too much weight to evidence based on a small number of observations. Using the classification in Beattie and Goodacre (2004), over a third (23) of the 63 journals are classified as non-core journals, covering mainly economics and management disciplines; this reflects the diversity of output from the accounting and finance community previously identified (Beattie and Goodacre, 2004).

\section{Metric 2: Aggregate pairwise comparisons}

Table 4 summarises the pairwise comparisons in an alternative aggregated form. It shows the total number of times a journal was preferred over any other journals (wins) and the total number of times it was not (losses). The table is ranked on the aggregate preference ratio of wins/losses. In this analysis, seven journals with low submissions are ranked top; these include four outside mainstream accounting and finance as well as three that have been consistently ranked highly in prior studies (Journal of Accounting Research, Journal of Financial and Quantitative Analysis and Journal of Financial Economics). The Journal of Finance ranks next, marginally above the Journal of International Money and Finance, followed by Accounting Organizations and Society and the Journal of Banking and Finance. The top six in the previous analysis maintain their high rankings (here 10,11, 13, 15-17) but the relative rankings of Accounting, Business and Financial History and European Financial Management decline to 39 and 41, respectively. The Review of Financial Studies fares less well (ranking 31) than suggested by its association with RAE 7-graded UoAs reported earlier in Table 2.

\section{$<$ Table 4 about here>}

\section{Metric 3: Aggregate submission to publication ratio}

This metric is based on the expectation that a large proportion of the available papers from journals perceived to be of high quality (assumed to include high quality papers) would be submitted to RAE 2001; lower proportions would be expected for lower quality journals. This suggests a correlation between journal quality and the proportion of available papers submitted. Table 5 reports the number of papers from each journal submitted to RAE 2001 and the total number of papers published in that journal by the same research-active staff over the same 1996-2000 period based on listings in the British Accounting Review Research Registers. The publication numbers have been adjusted for all RAE submissions that had been omitted from the Registers. This data allows the submission to publication ratio to be calculated.

\section{< Table 5 about here>}

In Panel A of Table 5 the 63 journals are ranked on the total combined aggregate RAE submission to publication ratio (penultimate column), with the journal ranking from a recent UK perception survey (Brinn et al., 1996) included in the final column for comparison. There are 7 journals for which $100 \%$ of the available papers were submitted to RAE 2001. This group includes the Journal of Financial and Quantitative Analysis, Journal of Accounting Research, Accounting and Business Research and Journal of Financial Economics. The Journal of Finance ranks next with a ratio of 95\%. All of these were rated highly in the Brinn et al. (1986) survey. The top twenty journals include eight finance journals plus the Journal of Business Finance and Accounting, six of which were not included in the Brinn et al. survey, including some relatively new journals. This 
implies that some journals seem able to establish a high reputation very quickly and confirms the need for regular reappraisal of relative journal quality. Of the remaining 11 journals in the top 20, three are accounting and eight are non-core economics and management journals. The inclusion of nine finance, but only three accounting, journals in this top group may reflect the fact that finance journals are more accessible to UK staff, in view of the globalisation of markets; by contrast, accounting remains a more local discipline (Lukka and Kasanen, 1996).

The next 15 journals, in the submission to publication ratio range down to $65 \%$, include four that would be regarded as core 'quality' journals for the accounting and finance community. Several more core journals are observed with ratios above 55\%. The relatively low rating for Critical Perspectives on Accounting may result partially from the inclusion of very short items (such as poems) in the available publications lists ${ }^{16}$; also, perhaps certain staff publish relatively frequently in this specialist journal so not all could be submitted to RAE 2001. Ten journals have a submission to publication ratio of $50 \%$ or less.

Panel B of Table 5 repeats the above analysis for those journals ranked in the Brinn et al. (1996) survey for which less than 5 papers were submitted to RAE 2001. This is included for completeness but should be interpreted with particular caution, given the small number of observations. It is important to note that all of the 9 journals with submission to publication ratios of $100 \%$ are based in the US or Canada, indicating the relative infrequency with which UK-based academics publish in these journals (Brinn et al., 2001). A further five journals ranked in Brinn et al. (1996) do not feature in either Panel A or Panel B as no papers were submitted to RAE 2001 by staff from the accounting and finance community. The omitted journals (with Brinn et al. (1996) ranks in brackets) are: Accounting Review (5); Journal of Accounting Literature (13); Behavioral Research in Accounting (20); Advances in Accounting (23); Accounting and Finance (41).

\section{Metric 4: Weighted average RAE grade (RAE metric)}

Table 6 reports the ranking of the 63 journals based on the RAE 2001 grades. The RAE metric (weighted average RAE grade) is calculated for each journal using the total number of submissions from UoAs as weights; Columns 2, 5 and 8 show the mean RAE grade based on submissions to the A\&F panel, B\&M panel and combined results. To enable a judgement on the strength of the evidence, the number of submissions (no subs) on which each ranking is based is reported in columns 3,6 and 10. The ranking of some journals based on submissions to the separate panels is either not possible (no submissions) or needs to be treated with utmost caution given the very small number of submissions. The overall results are based on a minimum of five submissions. The overall median RAE grade is reported in column 9 and the final column reports the overall rank based on combined submissions. For the 63 journals in Table 6, the mean RAE metric is 5.98 for the A\&F panel, 5.37 for B\&M and 5.62 overall. $^{17}$

\section{$<$ Table 6 about here>}

Consider first the overall results (columns 8 to 11). All of the submissions to RAE 2001 for the top three journals (Journal of Accounting Research, Review of Economic Studies, and Review of Financial Studies) came from UoAs ranked $7\left(5^{*}\right)$ by the peer review panels, so they achieve a RAE metric of 7.0. The next three journals (Journal of Financial Economics, Journal of Finance and Economic Journal) came predominantly from UoAs ranked 7, so achieve RAE metrics in the top group (RAE metric >6.5). It is worth noting that three of the top 6 journals are in the finance area, two are in economics with only one in accounting. The next group (relating to UoA transformed rank 6) is the largest and 
comprises 30 journals including most of the major UK-based journals. Also noteworthy is the inclusion of five history-oriented journals in this second group. The final two groups relating to transformed ranks 5 and 4 contain 20 and 7 journals, respectively.

Given the difference between the mean RAE grades awarded by the A\&F and B\&M panels, it is important to assess whether this might introduce any systematic bias into the overall ranking based on combined grades. The difference in absolute grades should not affect the combination as long as the relative ranking of journals is similar across the two panels. The rank correlation between the $A \& F$ panel rank and the overall rank was calculated based on all journals with at least a modicum of evidence (taken as at least 2 submissions). For journals with at least 2 submissions to the A\&F panel $(n=43)$ the correlation is 0.81 and for journals with at least 3 submissions $(n=27)$ it is 0.91 . This high level of correlation suggests that the combination of A\&F and B\&M panel grades is not introducing significant bias into the rankings.

\section{Summary by discipline}

The final analysis seeks to summarise the rankings using the three aggregate metrics in the present paper (metrics 2 through 4) and compare these with the more recent perception survey studies from the UK (Brinn et al., 1996; Lowe and Locke, 2005) and internationally (Ballas and Theoharakis, 2003; Oltheten, Theoharakis and Travlos, 2005). Also, in contrast with the focus of the paper thus far, it provides separate analysis for the disciplines of accounting and finance (and other related areas). Table 7 summarises the various rankings for the 63 journals, while Table 8 gives rank correlations between these.

The overall ranking of the journals, based on the mean of the three ranks in Tables 4 through 6 , is reported in column 7 of Table 7. The table is split into three panels representing the major disciplines: Panel A reports 26 accounting journals; Panel B 16 finance journals; Panel $\mathrm{C}$ the remaining 23 non-core journals (2 journals are included in both accounting and finance panels). The ranking of the journals within the separate disciplines is reported in column 8. The ranking of these same journals in the four perception studies is reported in columns 9 through 14. The original ranks reported in these studies are shown, rather than the ranks based on only the set of journals included in Table 7.

\section{$<$ Table 7 about here>}

The perception studies ranked between 30 and 44 journals, of which approximately half had less than 5 submissions to RAE 2001 so are excluded from the analysis (and rankings) in the present paper. For example, Brinn et al. (1996) (Table 7: column 9) ranked 44 journals, only 23 of which feature as significant contributors to RAE 2001. Of these 23, 16 have been classified as accounting journals, 3 as finance, 2 as joint accounting and finance and 2 as non-core journals. The top two journals in Brinn et al. (1996) were financeoriented (Journal of Finance and Journal of Financial and Quantitative Analysis), with Journal of Accounting and Economics ranked third. The latter had just two publications from the accounting and finance community in the 5 year period, both of which were submitted to RAE 2001. This means that the Journal of Accounting Research, ranked fourth in Brinn et al. (1996), represents the top-ranked accounting journal of significance in RAE 2001 (i.e. included in Table 7, panel A).

The present ranking of accounting journals (Panel A) is broadly similar to the ordering of the same journals in the recent survey studies of accounting journals. Two of the top four journals in the present study (Journal of Accounting Research and Accounting Organizations and Society) were the highest ranked of the mutual journals in all four 
accounting surveys. Similarly, the other two in the top four journals in the present study were ranked highly in the perception surveys. Accounting and Business Research was ranked 11th, 7th, 6th and 18th in the surveys (which translates to 5th, 3rd, 4th, and 4th of the accounting journals mutual to surveys and present study) and Journal of Business Finance and Accounting ranked 10th, 8th, 15th and 22nd in the accounting surveys (4th, 4 th, 10th and 5th of the mutual journals). Two journals generally rank somewhat higher in the present study (Accounting Historians Journal and Journal of International Accounting, Auditing and Taxation) and three journals rank lower (Journal of International Financial Management and Accounting, Critical Perspectives on Accounting and Financial Accountability and Management). It is also interesting to note that European academics (Ballas and Theoharakis, 2003) rank the European Accounting Review and Accounting Education more highly than UK academics (present study and Brinn et al., 1996) but history-oriented journals lower.

For the set of finance journals (Panel B), there is even greater similarity between the rankings in the present study and the ordering in the survey of finance journals by Oltheten et al. (2005). The top four are identical (though in slightly different order) to both European and US-based rankings and none of the journals is ordered significantly differently.

Panel $\mathrm{C}$ indicates that four non-core journals rank within the overall top ten of those submitted to RAE 2001 by the accounting and finance community.

In Table 8, the correlations between rankings on the four alternative metrics and the overall ranking used in the present study are all reasonably strong and statistically significant. Encouragingly, the detailed individual pairs comparison correlates strongly with the other metrics and particularly with the overall rank (coefficient $=0.96$ ). All five measures are strongly associated with the ranking of accounting journals by Lowe and Locke (2005) (correlations in the range 0.73 to 0.97), and with Brinn et al.'s (1996) rankings (correlations in the range 0.68 to 0.84 ), probably reflecting the fact that both are ultimately based on the perceptions of the UK accounting and finance community. Correlations between the present rankings and the international surveys are still pretty strong but are, perhaps surprisingly, generally higher with the US than with European perceptions.

\section{$<$ Table 8 about here>}

Further comparisons with the recent perception survey studies are also enlightening. In particular, there is relatively little overlap between RAE 2001 submissions and the journals included in the surveys. Of the 44 journals included in the Brinn et al. (1996) UK survey, 21 had a relatively small impact on RAE 2001 (thereby excluded from Table 7) with a total of just 31 submissions, representing $2 \%$ of the total. Thus, 23 of the Brinn et al. (1996) journals plus an additional 40 journals made up the vast majority of submissions. These 40 journals include 8 accounting, 11 finance, 8 economic and 13 business and management journals. Thirty accounting journals were ranked in Lowe and Locke (2005), but only 16 featured significantly in RAE 2001.

Of the 58 accounting journals covered in the international survey by Ballas and Theoharakis (2003), 20 contributed to RAE 2001 (per Table 7) but 38 did not. Of 66 finance journals listed in the Oltheten et al. (2005) survey, just 15 contributed to RAE 2001 but 51 did not. Overall, 30 of the journals contributing to RAE 2001 were not included in either of these two surveys. Of these 30, 15 were business and management journals, 7 were economic journals, 6 were accounting and 2 finance. These observations 
reflect the considerable diversity of output locations for the UK accounting and finance community, as highlighted by Beattie and Goodacre (2004).

\section{Conclusion}

Given the many and varied uses to which journal rankings are put, interest in such rankings will persist. Unfortunately, existing methods of constructing such rankings all have significant inherent limitations. This paper proposes a new (complementary) approach that is not restricted to a pre-defined journal set and, importantly, is based on quality choice decisions driven by economic incentives. Further, the limitations of the present methods are different to those of alternative approaches so the study contributes by providing triangulation for prior studies.

Four metrics are proposed, based on the submission choices made in RAE 2001. Using information from research-active individuals' quality decisions, two rankings were based on pairwise comparisons between journals: first, for a subset of journals using the individual comparisons; second, for all 63 significant RAE 2001 journals using the overall preference ratio for each journal. At the aggregate level, the 'submission to publication ratio' is reported for the same set of journals (with five or more papers submitted to RAE 2001). Fourthly, a weighted average RAE grade (RAE metric) based on the RAE 2001 peer review panel judgements was used. Finally, rankings from the three metrics which could be applied to the full set of 63 journals were combined to produce an overall ranking. Strong correlations were observed between the rankings based on the different metrics and also with the Lowe and Locke (2005) and Brinn et al. (1996) rankings. However, a large number of submissions to RAE 2001 were from journals that are not included in the recent perception survey studies, reflecting the eclecticism within the UK accounting and finance community. Thus, the paper provides a timely analysis of relative journal quality across a wide number of journals of direct relevance to non-US academics.

As with all methods of journal ranking, the present rankings need to be interpreted with care. The metrics used are all proxies for the underlying unobservable construct of interest, which is journal quality. Each of the proxies suffers from (usually different) limitations. For example, the two proxies involving journal comparisons at the individual level may be affected by the strategic allocations of jointly authored papers to specific individuals (as discussed earlier). This does not affect the other two proxies as the measurement takes place either at the UoA level (RAE metric) or across all UoAs. One limitation across all proxies is that they are subject to sampling error since the metrics are based on a relatively small number of observations for some journals. A further issue that cannot be addressed in this study, or by any ranking based on historical data, relates to the dynamic nature of journals and of journal quality. New journals arise, editors and editorial policies change over time so the perceptions of quality on which this paper is based may already have modified. Finally, the metrics can only proxy for the average quality within a particular journal, but the quality of individual papers will vary about the average and will depend on many factors including the quality of the review process. The assessment of the quality of an individual paper remains a matter for expert peer evaluation. ${ }^{18}$ 


\section{References}

Alexander, J.C. and Mabry, R.H. (1994), 'Relative significance of journals, authors, and articles cited in financial research', Journal of Finance, 49(2), June, pp. 697-712.

Ballas, A. and Theoharakis, V. (2003), 'Exploring diversity in accounting through faculty journal perceptions', Contemporary Accounting Research, 20(4), pp. 619-644.

Beattie, V.A. and Goodacre, A. (2004), 'Publishing patterns within the UK accounting and finance academic community', British Accounting Review, 36(1), March, pp. 7-44.

Bertin. W.J., Prather, L. and Zivney, T.L. (1994), 'University library collections of finance periodicals', Financial Practice and Education, 4(2), Fall/Winter, pp. 99-105.

Brinn, T., Jones, M.J. and Pendlebury, M. (1996), 'UK accountants' perceptions of research journal quality', Accounting and Business Research, 26(3), Summer, pp. 265278.

Brinn, T., Jones, M.J. and Pendlebury, M. (2001), 'Why do UK accounting and finance academics not publish in top US journals?', British Accounting Review, 33(2), June, pp. 223-232.

Brown, L.D. (2003), 'Ranking journals using Social Science Research Network downloads', Review of Quantitative Finance and Accounting, 20(3), May, pp. 291-307.

Brown, L.D. and Gardner, J.C. (1985), 'Using citation analysis to assess the impact of journals and articles on contemporary accounting research', Journal of Accounting Research, 23(1), Spring, pp. 84-109.

Brown, L.D. and Huefner, R.J. (1994), 'The familiarity with and perceived quality of accounting journals: views of senior accounting faculty in leading U.S. MBA programs', Contemporary Accounting Research, 11(1), Summer, pp. 223-250.

Brown, L.D. and Laksmana, I. (2003), 'Ranking accounting PhD programs and faculties using Social Science Research Network downloads', Review of Quantitative Accounting and Finance, 22(3), pp. 249-266.

Chan, K.C., Fok, R.C.W. and Pan, M-S. (2000), 'Citation-based finance journal rankings: an update', Financial Practice and Education, 10(1), Spring/Summer, pp. 132-141.

Dawson, J., Findlay, A. and Sparks, L. (2004), 'The UK research assessment exercise (RAE) 2001 and retail research output', International Review of Retail, Distribution and Consumer Research, 14(4), October, pp. 479-491.

Durden, C.H., Wilkinson, B.R. and Wilkinson, K.J. (1999), 'Publishing productivity of Australian accounting 'units' based on current faculty composition', Pacific Accounting Review, 11(1), June, pp. 1-27.

Easton, G. and Easton, D.M. (2003), 'Marketing journals and the research assessment exercise', Journal of Marketing Management, 19(1/2), February, pp.5-24. 
Geary, J., Marriott, L. and Rowlinson, M. (2004), 'Journal rankings in business and management and the 2001 research assessment exercise in the UK', British Journal of Management, 15(2), June, pp. 95-141.

Gray, R.H. and Helliar, C. (1994), 'UK accounting academics and publication: an exploration of observable variables associated with publication output', British Accounting Review, 26(3), September, pp. 235-254.

Hasselback, J.R., Reinstein, A. and Schwan, E.S. (2000), 'Benchmarks for evaluating the research productivity of accounting faculty', Journal of Accounting Education, 18(2), pp. 79-97.

Helliar, C.V. and Gray, R.H. (1998), British Accounting Review Research Register 1998, eighth edition, London, Academic Press.

Helliar, C.V. and Gray, R.H. (2000), British Accounting Review Research Register 2000, ninth edition, London, Academic Press.

Helliar, C.V., Gray, R.H. and Monk, E.A. (2002), British Accounting Review Research Register 2002, tenth edition, London, Academic Press.

Hickman, K.A. and Shrader, M.J. (2000), 'Predicting the productivity of new finance professors', Financial Practice and Education, 10(1), Spring/Summer, pp. 93-98.

Hull, R.P. and Wright, G.B. (1990), 'Faculty perceptions of journal quality: an update', Accounting Horizons, 4(1), March, pp. 77-98.

Jones, M.J., Brinn, T. and Pendlebury, M. (1996), 'Journal evaluation methodologies: a balanced response', Omega, International Journal of Management Science, 24(5), pp. 607-612.

Locke, J. and Lowe, A. (2002), 'Problematising the construction of journal quality: an engagement with the mainstream', Accounting Forum, 26(1), March, pp. 45-71.

Lowe, A. and Locke, J. (2005), 'Perceptions of journal quality and research paradigm: results of a web-based survey of British accounting academics', Accounting, Organizations and Society, 30(1), January, pp. 81-98.

Lukka, K. and Kasanen, E. (1996), 'Is accounting a global or a local discipline? Evidence from major research journals', Accounting, Organizations and Society, 21(7/8), pp. 755773.

Oltheten, E., Theoharakis, V., and Travlos, N.G. (2005), 'Faculty perceptions and readership patterns of finance journals: a global view', Journal of Financial and Quantitative Analysis, 40(1), March, pp. 223-239.

Otley, D. (2002), 'British research in accounting and finance (1996-2000): the 2001 research assessment exercise', British Accounting Review, 34(4), December, pp. 387-417. Parker, L., Guthrie, J. and Gray, R. (1998), 'Accounting and management research: passwords from the gatekeepers', Accounting, Auditing \& Accountability Journal, 11(4), pp. 371-402. 
RAE (1999), Research Assessment Exercise 2001: Assessment panels' criteria and working methods (RAE 5/99), December.

RAE (2001), http://www.hero.ac.uk/rae/.

RAE (2008), Consultation on assessment panels' draft criteria and working methods (RAE 04/2005), http://www.rae.ac.uk/pubs/2005/04/, July.

Wilkinson, B.R. and Durden, C.H. (1998), 'A study of accounting faculty publishing productivity in New Zealand', Pacific Accounting Review, 10(2), December, pp. 75-95.

Zeff, S.A. (1996), 'A study of academic research journals in accounting', Accounting Horizons, 10(3), September, pp. 158-177. 


\section{Endnotes}

${ }^{1}$ The outputs were either submitted directly or were cross-referred from another panel (see section 3).

${ }^{2}$ It was possible for a university to trade off the rank obtained with the number of staff submitted. For example, a unit that believed itself to be on the borderline between 4 and 5 might choose to omit some staff of national (rather than international) excellence in the hope of obtaining the 5 rank. If successful, it would obtain the higher funding rate (unknown ex ante) associated with the 5, but multiplied by the lower number of staff submitted. The university would presumably make this decision based on the expected overall funding (Otley, 2002). This means that some genuinely 'research-active' staff may have been omitted from the RAE 2001 process; these staff have also been excluded from our analysis.

${ }^{3}$ Having worked with the BAA Research Registers previously, our priors were that they represent a reasonably accurate record of output by the A\&F community. Some errors we have been able to correct in constructing the database, though some will remain. To assess the accuracy of our Registers database, we manually checked all of the papers from the 63 journals with 5 or more submissions to RAE 2001 (i.e. those in Tables 4 to 7) against entries in the Registers. Of the 1032 papers, 854 (82.8\%) papers were included within the Registers. 88 (8.5\%) were papers that had been published by individuals prior to their entry into the A\&F community; these researchers had perhaps moved to the UK from abroad, or moved into an A\&F group from another discipline. 16 (1.6\%) papers were submitted to RAE 2001 twice by the same individual (so were included once in the database but twice in RAE 2001). 74 (7.2\%) papers were omitted from the Registers in error. In a large majority of cases these related to researchers who had moved between institutions and the publication had not been recorded by either institution. The rest presumably relate to inaccurate recording by the researcher or reporting by the institution. Thus, our best estimate of the actual error rate in the Registers is $7.2 \%$.

${ }^{4}$ The choice of one article over another is presumed to be based on perceptions of relative journal quality. However, it might also be based on other factors such as a lengthy contribution being preferred to a shorter note or comment, or an article based on empirical data or a novel method of data analysis being preferred to a more discursive piece.

${ }^{5}$ As indicated in note 3 above, every submission from the main journals (those analysed in Tables 4-7) was checked against the BAR Research Registers. Overall, $17.2 \%$ of submissions were, for one reason or another, not included in the Registers. The omission rate was lower for journals that had a large number of submissions to RAE 2001; e.g. for journals with 15 or more submissions it was $12.1 \%$. For metric 3 (aggregate submission/publication rate) calculations, the total number of available publications from each journal has been increased to take account of these omissions.

6 A similar measure has been adopted for other related disciplines: business and management (Geary, Marriott and Rowlinson, 2004); retailing (Dawson, Findlay and Sparks, 2004); and marketing (Easton and Easton, 2003). In the latter study the authors describe the measure using the term 'RAE Implied Journal Quality' (RIJQ); the Cusum Index they report in Table 5 produces an identical ranking to the measures reported in Geary et al. and in the current study.

${ }^{7}$ For UoAs in Scotland the equivalent ratios (starting at $5^{*}$ ) were not dissimilar at $3.2 ; 2.8 ; 1.55 ; 1 ; 0 ; 0 ; 0$ (Otley, 2002).

${ }^{8}$ The studies of RAE-based journal rankings in other related disciplines focused on journals with a minimum frequency of three (Geary et al., 2004) or six (Easton and Easton, 2003; Dawson et al., 2004).

${ }^{9}$ We are grateful to one of the reviewers for highlighting these two limitations.

10 At three institutions (Durham, Edinburgh and Manchester Universities), some of the accounting and finance community staff were submitted to the A\&F and some to the B\&M panel, so the number of different institutions is 76 .

${ }^{11}$ Analysis of this summary across the two separate RAE panels shows that, overall, output for 225 (2700) research active staff from 20 (97) different institutions was submitted to the A\&F (B\&M) peer-review panel. 677 (7975) items of output were journal papers and 134 (1967) were other forms of output such as book chapters, discussion papers etc. For the A\&F panel, 204 (91\%) of the total 225 research active staff were from the accounting and finance community; the remaining $21(9 \%)$ were mainly economists who were 
included within submissions from certain institutions. For the B\&M panel, 321 (11.9\%) staff were from the 'accounting and finance community' and submitted 959 journal papers to RAE 2001.

12 The Journal of Finance is excluded from this analysis as there were almost no direct comparisons available between Journal of Finance and other journals in the table. The twelve individuals from the A\&F community with RAE 2001 submissions from Journal of Finance tended to publish in other journals not readily accessible to UK researchers.

${ }^{13}$ The explanation for this observation is that the Accounting and Business Research papers were jointly authored with others at the same institution and were 'allocated' to one of the other authors to improve the institution's overall quality of papers submitted to RAE 2001.

${ }^{14}$ There are a three further inconsistencies (not shaded in the matrix) that relate to pairwise comparison highscore 'draws' (i.e. equal number of wins and losses). All three involve the European Accounting Review: with Accounting, Auditing and Accountability Journal (6 wins and 6 losses), with Critical Perspectives on Accounting and with Management Accounting Research (both 3 wins and 3 losses). These suggest a wide variation in perception of the quality of papers in European Accounting Review. The positive and negative inconsistencies in the International Journal of Auditing comparisons also suggest a wide variation in perception.

${ }^{15}$ An alternative approach to ranking based on these pairwise comparisons can be undertaken by treating each comparison as the result of a game between the two, analogous to a soccer game. Continuing the soccer analogy enables a league table to be constructed based on the results for each team (journal). Various points systems were assessed and a modified version of the current UK soccer league system was considered reasonable. It seemed important to recognise that a score draw (e.g. Win 1 Loss 1) conveyed greater information than a no-score draw (which implies no comparisons between two journals were available). So a table was constructed based on the following: overall win $=3$ points; 'score' draw $=2$ point; 'no-score' draw $=1$ point; loss $=0$ points). In this league table, the Journal of Banking and Finance came marginally top with 40 points ( 11 wins; 1 'score' draw; 5 'no-score' draws; and a win/loss (goal) difference of +32 ), closely followed by Accounting and Business Research on 39 points (W 11; SD 3; NSD 0; WL diff +29) and Accounting Organizations and Society with 37 points (W 10; SD 0; NSD 7; WL diff +33 ). The marginally changed ranking reflects the additional information which is aggregated within the league measures and the reduced emphasis on the results of individual 'games' between the top teams (journals). Overall, the ranking was similar to that reported in Table 3 (Spearman correlation $=0.924$ ) with a maximum rank change of \pm 4 .

${ }^{16}$ Unfortunately, it was not possible based on the available publications database to separate out such minor 'publications' for Critical Perspectives on Accounting or for other journals which feature such items.

${ }^{17}$ As a benchmark, for the full set of journal paper submissions by the accounting and finance community, the mean RAE grade (metric 4) was 5.97 for the A\&F panel, 5.22 for B\&M and 5.51 overall.

${ }^{18}$ For the 2008 research assessment exercise, it has already been stated that 'the assessment will be one of peer review based on professional judgement'. The panels concerned do not intend to use ranked lists of journals, mainly on the grounds that there is considerable variability of quality within journals (RAE, 2008). 


\section{Table 1 Summary statistics of research-active staff}

\section{Panel A}

Research-active staff submitted to either $A \& F$ or B\&M panel (per RAE 2001)

\begin{tabular}{|c|c|c|c|c|c|c|}
\hline \multirow{2}{*}{\multicolumn{2}{|c|}{ RAE 2001 grade }} & \multirow[b]{3}{*}{ No of staff } & \multirow[b]{3}{*}{ No of inst ${ }^{1}$} & \multicolumn{3}{|c|}{ Number of outputs (per RA2) ${ }^{2}$} \\
\hline & & & & Academic & & \\
\hline Original & Transformed & & & journal papers & Others & Total \\
\hline 1 & 1 & 13 & 3 & 20 & 27 & 47 \\
\hline 2 & 2 & 172 & 15 & 441 & 182 & 623 \\
\hline 3b & 3 & 279 & 18 & 851 & 176 & 1027 \\
\hline $\mathbf{3 a}$ & 4 & 568 & 25 & 1694 & 401 & 2095 \\
\hline 4 & 5 & 752 & 26 & 2310 & 427 & 2737 \\
\hline 5 & 6 & 793 & 25 & 2388 & 541 & 2929 \\
\hline $5^{*}$ & 7 & 348 & 5 & 948 & 347 & 1295 \\
\hline & & 2925 & 117 & 8652 & 2101 & 10753 \\
\hline
\end{tabular}

\section{Panel B}

Research-active staff submitted from $A \& F$ community to either $A \& F$ or $B \& M$ panel (per BAR research registers)

\begin{tabular}{|c|c|c|c|c|c|c|}
\hline \multirow{2}{*}{\multicolumn{2}{|c|}{ RAE 2001 grade }} & \multirow[b]{3}{*}{ No of staff } & \multicolumn{4}{|c|}{ Number of outputs (per RA2) ${ }^{2}$} \\
\hline & & & & Academic & & \\
\hline Original & Transformed & & No of inst ${ }^{1}$ & journal papers & Others & Tota \\
\hline 1 & 1 & 0 & 0 & 0 & 0 & 0 \\
\hline 2 & 2 & 6 & 4 & 19 & 3 & 22 \\
\hline $3 \mathbf{b}$ & 3 & 32 & 13 & 100 & 19 & 119 \\
\hline 3a & 4 & 53 & 15 & 158 & 35 & 193 \\
\hline 4 & 5 & 126 & 19 & 401 & 57 & 458 \\
\hline 5 & 6 & 186 & 23 & 573 & 107 & 680 \\
\hline $5 *$ & 7 & 122 & 5 & 326 & 108 & 434 \\
\hline & & 525 & 79 & 1577 & 329 & 1906 \\
\hline
\end{tabular}

Notes

1. Strictly this represents the number of separate submissions by institutions, as submissions by the same institution to the A\&F and B\&M panels are counted twice.

2. Full credit is given to the submitted individual for jointly-authored publications. 
Table 2: Summary of academic journal papers submitted to RAE 2001 by research-active staff from the accounting and finance community

Panel A: The most frequently submitted journals

Total number of journal submissions to RAE 2001 by staff in UoAs with transformed grade $=$

$\%$ of all

Rank Journal

\begin{tabular}{|c|c|c|c|c|c|c|c|}
\hline 2 & 3 & 4 & 5 & 6 & 7 & Total & submitted \\
\hline 0 & 5 & 3 & 22 & 66 & 26 & 122 & $7.74 \%$ \\
\hline 0 & 2 & 2 & 7 & 37 & 16 & 64 & $4.06 \%$ \\
\hline 1 & 0 & 3 & 21 & 26 & 7 & 58 & $3.68 \%$ \\
\hline 1 & 4 & 6 & 18 & 21 & 6 & 56 & $3.55 \%$ \\
\hline 0 & 0 & 2 & 20 & 20 & 6 & 48 & $3.04 \%$ \\
\hline 0 & 1 & 4 & 13 & 20 & 9 & 47 & $2.98 \%$ \\
\hline 0 & 0 & 0 & 4 & 21 & 16 & 41 & $2.60 \%$ \\
\hline 0 & 4 & 0 & 10 & 15 & 7 & 36 & $2.28 \%$ \\
\hline 0 & 1 & 8 & 10 & 13 & 0 & 32 & $2.03 \%$ \\
\hline 0 & 0 & 2 & 9 & 11 & 10 & 32 & $2.03 \%$ \\
\hline 0 & 3 & 5 & 7 & 8 & 0 & 23 & $1.46 \%$ \\
\hline 0 & 0 & 1 & 3 & 11 & 7 & 22 & $1.40 \%$ \\
\hline 0 & 0 & 7 & 10 & 4 & 1 & 22 & $1.40 \%$ \\
\hline 0 & 1 & 2 & 12 & 4 & 3 & 22 & $1.40 \%$ \\
\hline 0 & 0 & 1 & 1 & 3 & 13 & 18 & $1.14 \%$ \\
\hline 0 & 0 & 1 & 4 & 6 & 6 & 17 & $1.08 \%$ \\
\hline 1 & 1 & 0 & 6 & 2 & 7 & 17 & $1.08 \%$ \\
\hline 0 & 0 & 3 & 6 & 4 & 2 & 15 & $0.95 \%$ \\
\hline 1 & 2 & 4 & 5 & 2 & 0 & 14 & $0.89 \%$ \\
\hline 0 & 0 & 1 & 5 & 7 & 1 & 14 & $0.89 \%$ \\
\hline 1 & 1 & 0 & 9 & 1 & 1 & 13 & $0.82 \%$ \\
\hline 1 & 3 & 3 & 2 & 4 & 0 & 13 & $0.82 \%$ \\
\hline 0 & 0 & 1 & 4 & 2 & 6 & 13 & $0.82 \%$ \\
\hline 0 & 0 & 0 & 0 & 0 & 12 & 12 & $0.76 \%$ \\
\hline 0 & 2 & 1 & 3 & 4 & 1 & 11 & $0.70 \%$ \\
\hline 0 & 0 & 2 & 7 & 2 & 0 & 11 & $0.70 \%$ \\
\hline 0 & 1 & 1 & 3 & 4 & 1 & 10 & $0.63 \%$ \\
\hline 0 & 1 & 1 & 1 & 4 & 3 & 10 & $0.63 \%$ \\
\hline 0 & 1 & 1 & 1 & 4 & 2 & 9 & $0.57 \%$ \\
\hline 0 & 1 & 0 & 7 & 1 & 0 & 9 & $0.57 \%$ \\
\hline 0 & 0 & 0 & 2 & 5 & 2 & 9 & $0.57 \%$ \\
\hline 19 & 100 & 158 & 401 & 573 & 326 & 1577 & $100 \%$ \\
\hline 18 & 68 & 100 & 155 & 190 & 128 & 408 & \\
\hline
\end{tabular}

Panel B: Distribution of journal submission numbers

Number of journals with submissions totalling

\begin{tabular}{cccc} 
freq & $\%$ & $\begin{array}{c}\text { Cum } \\
\text { freq }\end{array}$ & $\begin{array}{c}\text { Cum } \\
\%\end{array}$ \\
4 & $1.0 \%$ & 4 & $1.0 \%$ \\
6 & $1.5 \%$ & 10 & $2.5 \%$ \\
4 & $1.0 \%$ & 14 & $3.4 \%$ \\
12 & $2.9 \%$ & 26 & $6.4 \%$ \\
24 & $5.9 \%$ & 50 & $12.3 \%$ \\
66 & $16.2 \%$ & 116 & $28.4 \%$ \\
75 & $18.4 \%$ & 191 & $46.8 \%$ \\
217 & $53.2 \%$ & 408 & $100.0 \%$ \\
\cline { 1 - 1 } 408 & $100.0 \%$ & &
\end{tabular}




\begin{tabular}{|c|c|c|c|c|c|c|c|c|c|c|c|c|c|c|c|c|c|c|c|c|c|c|c|c|c|c|c|c|c|c|c|c|c|c|c|c|}
\hline \multicolumn{37}{|c|}{ Table 3: Ranking based on metric 1: individual pairwise comparisons } \\
\hline & \multirow[b]{3}{*}{ rank } & \multirow{3}{*}{\begin{tabular}{|c|}
$\mathbf{A O S}$ \\
$\mathrm{W}$ \\
\end{tabular}} & \multirow{3}{*}{\begin{tabular}{|l|l|} 
& \\
& $\mathbf{J}$ \\
$\mathbf{L}$ & \\
\end{tabular}} & \multirow{3}{*}{\begin{tabular}{l|}
$\mathbf{B F}$ \\
$\mathbf{W}$ \\
\end{tabular}} & \multirow{3}{*}{\begin{tabular}{|l|} 
\\
$\mathbf{L}$ \\
\end{tabular}} & \multirow{3}{*}{\multicolumn{2}{|c|}{\begin{tabular}{|c|c|}
\multicolumn{2}{|c|}{ JFutM } \\
W & $\mathbf{L}$ \\
\end{tabular}}} & \multirow{3}{*}{\begin{tabular}{|c|}
$\mathbf{A B R}$ \\
$\mathbf{W}$ \\
\end{tabular}} & \multirow{3}{*}{\begin{tabular}{l|l|}
$\mathbf{L}$ \\
\end{tabular}} & & & & & & & & & & & & & & & & & & & & & & & & & & & \\
\hline & & & & & & & & & & \multicolumn{2}{|c|}{ AAAJ } & \multicolumn{2}{|c|}{ JBFA } & \multirow{2}{*}{\begin{tabular}{|c|} 
CPA \\
$W$ \\
\end{tabular}} & \multicolumn{3}{|c|}{\begin{tabular}{l|l} 
MAR \\
\end{tabular}} & \multicolumn{2}{|c|}{ ABFH } & FAM & \multicolumn{2}{|c|}{ EFM } & \multirow{2}{*}{\begin{tabular}{|c|} 
BAR \\
$W$ \\
\end{tabular}} & & IJAud & & EAR & & $\mathbf{A F E}$ & & Aed & & EJOF & & JAAPI & pAR \\
\hline & & & & & & & & & & $\mathbf{W}$ & \begin{tabular}{|l|l}
$\mathbf{L}$ \\
\end{tabular} & \begin{tabular}{|l|l|}
$\mathbf{W}$ \\
\end{tabular} & $\mathbf{L}$ & & $\mathbf{L}$ & $\mathbf{W}$ & $\mathbf{L}$ & $\mathbf{W}$ & \begin{tabular}{|l|l}
$\mathbf{L}$ & \\
\end{tabular} & \begin{tabular}{|l|l|l|} 
W & L \\
\end{tabular} & \begin{tabular}{l|l|}
$\mathbf{L}$ & $\mathbf{W}$ \\
\end{tabular} & $\mathbf{L}$ & & $\mathbf{L}$ & \begin{tabular}{|l|l|}
$\mathbf{W}$ \\
\end{tabular} & $\mathbf{L}$ & \begin{tabular}{|l|}
$\mathbf{W}$ \\
\end{tabular} & \begin{tabular}{|l|l|l|l}
$\mathbf{L}$ & $\mathbf{2}$ \\
\end{tabular} & $\mathbf{W}$ & \begin{tabular}{l|l}
$\mathbf{L}$ & \\
\end{tabular} & $\mathbf{W}$ & $\mathbf{L}$ & \begin{tabular}{|l|}
$\mathbf{W}$ \\
\end{tabular} & $\mathbf{L}$ & W & \\
\hline Accounting Organizations and Society & 1 & & & 0 & 0 & 0 & 0 & 1 & 3 & 7 & 9 & 0 & 4 & 3 & 9 & 1 & 6 & 0 & 3 & 0 & 0 & 0 & 0 & 4 & 1 & 3 & 2 & 4 & 0 & 0 & 0 & 0 & 0 & 0 & 0 & 0 \\
\hline Journal of Banking and Finance & 2 & 0 & 0 & & & 0 & 1 & 0 & 2 & 1 & 1 & 2 & 7 & 0 & 1 & 0 & 0 & 0 & 1 & 0 & 1 & 4 & 0 & 2 & 0 & 0 & 0 & 0 & 0 & 11 & 0 & 2 & 0 & 3 & 0 & 0 \\
\hline Journal of Futures Markets & 3 & 0 & 0 & 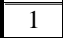 & 0 & & & 1 & 1 & 0 & 0 & 2 & 4 & 0 & 0 & 0 & 0 & 0 & 0 & 0 & 2 & 5 & 1 & 0 & $\overline{0}$ & 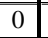 & 0 & 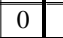 & 0 & 4 & 0 & 0 & $\overline{11}$ & 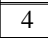 & 0 & 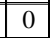 \\
\hline Accounting and Business Research & 4 & 3 & 1 & 2 & 0 & 1 & 1 & & & 3 & 4 & 12 & 13 & 0 & 3 & 3 & 5 & 1 & 1 & 4 & 2 & 3 & 2 & 9 & 1 & 1 & 3 & 8 & 0 & 2 & 0 & 8 & 0 & 5 & 0 & 2 \\
\hline Accounting Auditing and Accountability J & 5 & 9 & 7 & 1 & 1 & 0 & 0 & 4 & 3 & & & 1 & 3 & 14 & 16 & 8 & 10 & 0 & 5 & 5 & 0 & 0 & 4 & 7 & 1 & 6 & 6 & 6 & 0 & 0 & 0 & 5 & 0 & 0 & 0 & 3 \\
\hline Journal of Business Finance and Accounting & 6 & 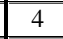 & 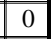 & 7 & 2 & 4 & 2 & 13 & 12 & 3 & 1 & & & 1 & 3 & 2 & 3 & 2 & 1 & 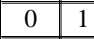 & 4 & 10 & 8 & 21 & 0 & 1 & 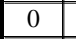 & 7 & 2 & 15 & 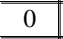 & 1 & 1 & 13 & 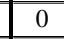 & 2 \\
\hline Critical Perspectives on Accounting & 7 & 9 & 3 & 1 & 0 & 0 & 0 & 3 & 0 & 16 & 14 & 3 & 1 & & & 1 & 4 & 0 & 3 & 2 & 0 & 0 & 4 & 5 & 3 & 2 & 3 & 3 & 1 & 0 & 0 & 5 & 0 & 0 & 0 & 9 \\
\hline Management Accounting Research & 8 & 6 & 1 & 0 & 0 & 0 & 0 & 5 & 3 & 10 & 8 & 3 & 2 & 4 & 1 & & & 0 & 1 & 0 & 0 & 0 & 5 & 6 & 4 & 0 & 3 & 3 & 0 & 0 & 2 & 5 & 0 & 1 & 0 & 4 \\
\hline Accounting Business and Financial History & 9 & 3 & 0 & 1 & 0 & 0 & 0 & 1 & 1 & 5 & 0 & 1 & 2 & 3 & 0 & $\overline{11}$ & 0 & & & 0 & 0 & 0 & 1 & 2 & 0 & 2 & 2 & 1 & 1 & 0 & 0 & 0 & 0 & 0 & 0 & 0 \\
\hline Financial Accountability and Management & 10 & 3 & 0 & 1 & 0 & 0 & 0 & 0 & 4 & 6 & 5 & 1 & 0 & 6 & 2 & 9 & 0 & 1 & 0 & & 0 & 0 & 4 & 5 & 0 & 2 & 0 & 4 & 0 & 0 & 1 & 4 & 0 & 0 & 0 & 0 \\
\hline European Financial Management & 11 & 0 & 0 & 4 & 1 & 5 & 2 & 3 & 2 & 0 & 0 & 10 & 4 & 0 & 0 & 0 & 0 & 0 & 0 & 0 & 0 & & 0 & 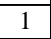 & 0 & 0 & 0 & 1 & 0 & 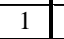 & 0 & 0 & 0 & 2 & 0 & 0 \\
\hline British Accounting Review & 12 & 4 & 0 & 2 & 0 & 0 & 1 & 9 & 2 & 7 & 4 & 21 & 8 & 5 & 4 & 6 & 5 & 2 & 1 & 5 & 4 & 0 & & & 1 & 3 & 4 & 5 & 0 & 2 & 3 & 4 & 3 & 4 & 1 & 5 \\
\hline International Journal of Auditing & 13 & 3 & 1 & 0 & 0 & 0 & 0 & 1 & 1 & 6 & 1 & 1 & 0 & 2 & 3 & 0 & 4 & 2 & 0 & 2 & 0 & 0 & 3 & 1 & & & 2 & 2 & 0 & 0 & 1 & 0 & 0 & 0 & 1 & 0 \\
\hline European Accounting Review & 14 & 4 & 2 & 0 & 0 & 0 & 0 & 8 & 3 & 6 & 6 & 7 & 0 & 3 & 3 & 3 & 3 & 1 & 2 & 4 & 1 & 0 & 5 & 4 & 2 & 2 & & & 0 & 0 & 0 & 2 & 0 & 1 & 0 & 0 \\
\hline Applied Financial Economics & 15 & 0 & 0 & 11 & 0 & 4 & 0 & 2 & 0 & 0 & 0 & 15 & 2 & 0 & 1 & 0 & 0 & 0 & 1 & 0 & 1 & 0 & 2 & 0 & 0 & 0 & 0 & 0 & & & 0 & 1 & 1 & 3 & 0 & 0 \\
\hline \begin{tabular}{|l|} 
Accounting Education \\
\end{tabular} & 16 & 0 & 0 & 2 & 0 & 0 & 0 & 8 & 0 & 5 & 0 & 1 & 0 & 5 & 0 & 5 & 2 & 0 & 0 & 4 & 0 & 0 & 4 & 3 & 0 & 1 & 2 & 0 & 1 & 0 & & & 0 & 0 & 0 & 1 \\
\hline European Journal of Finance & 17 & 0 & 0 & 3 & 0 & 4 & 1 & 5 & 0 & 0 & 0 & 13 & 1 & 0 & 0 & 1 & 0 & 0 & 0 & 0 & 2 & 0 & 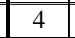 & 3 & 0 & 0 & 1 & 0 & 3 & 1 & 0 & 0 & & & 0 & 2 \\
\hline Journal of Applied Accounting Research & 18 & 0 & 0 & 0 & 0 & 0 & 0 & 2 & 0 & 3 & 0 & 2 & 0 & 9 & 0 & 4 & 0 & 0 & 0 & 0 & 0 & 0 & 5 & 1 & 0 & 1 & 0 & 0 & 0 & 0 & 1 & 0 & 2 & 0 & & \\
\hline & & & & & & & & & & & & & & & & & & & & & & & & & & & & & & & & & & & & \\
\hline Notes & & & & & & & & & & & & & & & & & & & & & & & & & & & & & & & & & & & & \\
\hline 1. W (L) = win (loss) for column journal ov & $v$ journ & al. Wi & in me & eans th & at a & paper & frol & & & & & & & & & & & & & & & & journal & & & & & & & & & & & & & \\
\hline Shaded cells indicate that the pairwise com & ison re & sult is & incol & nnsiste & nt wi & ith the & relat & ative rar & anking & $\mathrm{g}$ of the & two & o journa & als in & doicate & $a a_{1}$ & & & lumn in & nterse & ection. & & & & & & & & & & & & & & & & \\
\hline & & & & & & & & & & & & & & & & & & & & & & & & & & & & & & & & & & & & \\
\hline
\end{tabular}


Table 4: Ranking based on metric 2: aggregate pairwise comparisons (preference ratio)

\begin{tabular}{|c|c|c|c|c|c|}
\hline Rank & Journal & wins & losses & pref ratio & nosubs \\
\hline 1 & Academy of Management Journal & 27 & 0 & 1.000 & 7 \\
\hline 1 & Journal of Accounting Research & 12 & 0 & 1.000 & 5 \\
\hline 1 & Journal of Financial and Quantitative Analysis & 6 & 0 & 1.000 & 5 \\
\hline 1 & Journal of Financial Economics & 5 & 0 & 1.000 & 6 \\
\hline 1 & European Journal of Operational Research & 3 & 0 & 1.000 & 5 \\
\hline 1 & Review of Economic Studies & 3 & 0 & 1.000 & 5 \\
\hline 1 & Journal of the Operational Research Society & 2 & 0 & 1.000 & 9 \\
\hline 8 & Journal of Finance & 18 & 2 & 0.900 & 18 \\
\hline 9 & Journal of International Money and Finance & 14 & 2 & 0.875 & 13 \\
\hline 10 & Accounting Organizations and Society & 70 & 19 & 0.787 & 41 \\
\hline 11 & Journal of Banking and Finance & 55 & 15 & 0.786 & 32 \\
\hline 12 & Economic History Review & 13 & 4 & 0.765 & 5 \\
\hline 13 & Journal of Futures Markets & 26 & 11 & 0.703 & 17 \\
\hline 14 & Human Relations & 7 & 3 & 0.700 & 6 \\
\hline 15 & Accounting and Business Research & 120 & 57 & 0.678 & 64 \\
\hline 16 & Accounting Auditing and Accountability Journal & 121 & 65 & 0.651 & 58 \\
\hline 17 & Journal of Business Finance and Accounting & 143 & 80 & 0.641 & 122 \\
\hline 18 & Journal of International Accounting, Auditing and Taxation & 26 & 16 & 0.619 & 5 \\
\hline 19 & Manchester School of Economic and Social Studies & 17 & 11 & 0.607 & 14 \\
\hline 20 & International Journal of Accounting & 18 & 12 & 0.600 & 11 \\
\hline 20 & Abacus & 15 & 10 & 0.600 & 7 \\
\hline 22 & International Journal of Finance and Economics & 13 & 9 & 0.591 & 8 \\
\hline 23 & Journal of Management Studies & 11 & 8 & 0.579 & 6 \\
\hline 24 & European Finance Review & 4 & 3 & 0.571 & 5 \\
\hline 25 & Economics Letters & 17 & 13 & 0.567 & 6 \\
\hline 26 & Journal of International Financial Management and Accounting & 20 & 16 & 0.556 & 8 \\
\hline 27 & Critical Perspectives on Accounting & 81 & 67 & 0.547 & 48 \\
\hline 28 & Journal of Empirical Finance & 6 & 5 & 0.545 & 8 \\
\hline 29 & Management Accounting Research & 57 & 50 & 0.533 & 47 \\
\hline 30 & Financial Accountability and Management & 49 & 45 & 0.521 & 32 \\
\hline 31 & Business History & 11 & 11 & 0.500 & 6 \\
\hline 31 & Review of Financial Studies & 6 & 6 & 0.500 & 12 \\
\hline 31 & Organization Studies & 5 & 5 & 0.500 & 5 \\
\hline 34 & British Accounting Review & 81 & 90 & 0.474 & 56 \\
\hline 35 & Organization & 4 & 5 & 0.444 & 9 \\
\hline 36 & European Accounting Review & 44 & 57 & 0.436 & 36 \\
\hline 37 & Economic Journal & 3 & 4 & 0.429 & 6 \\
\hline 38 & International Journal of Auditing & 21 & 31 & 0.404 & 15 \\
\hline 39 & Accounting Business and Financial History & 18 & 29 & 0.383 & 22 \\
\hline 40 & British Journal of Management & 17 & 30 & 0.362 & 13 \\
\hline 41 & European Financial Management & 17 & 31 & 0.354 & 17 \\
\hline 42 & Accounting History & 15 & 31 & 0.326 & 10 \\
\hline 43 & Accounting Historians Journal & 5 & 11 & 0.313 & 7 \\
\hline 44 & Managerial Finance & 4 & 10 & 0.286 & 5 \\
\hline 45 & Corporate Governance: An International Review & 15 & 40 & 0.273 & 13 \\
\hline 46 & Applied Financial Economics & 17 & 47 & 0.266 & 22 \\
\hline 47 & Omega: International Journal of Management Science & 4 & 14 & 0.222 & 5 \\
\hline 47 & International Journal of Information Management & 2 & 7 & 0.222 & 6 \\
\hline 49 & Applied Economics & 3 & 11 & 0.214 & 7 \\
\hline 49 & Managerial Auditing Journal & 3 & 11 & 0.214 & 7 \\
\hline 51 & Journal of Financial Regulation and Compliance & 7 & 26 & 0.212 & 11 \\
\hline 52 & European Journal of Finance & 12 & 47 & 0.203 & 22 \\
\hline 53 & British Tax Review & 5 & 20 & 0.200 & 9 \\
\hline 53 & Journal of Economic Dynamics and Control & 1 & 4 & 0.200 & 6 \\
\hline 55 & Accounting Education & 10 & 50 & 0.167 & 23 \\
\hline 55 & Journal of Applied Accounting Research & 7 & 35 & 0.167 & 14 \\
\hline 57 & Long Range Planning & 3 & 16 & 0.158 & 6 \\
\hline 58 & Irish Accounting Review & 5 & 27 & 0.156 & 5 \\
\hline 59 & European Business Review & 1 & 8 & 0.111 & 6 \\
\hline 60 & Accounting Forum & 2 & 39 & 0.049 & 10 \\
\hline 61 & Public Money and Management & 2 & 51 & 0.038 & 8 \\
\hline 62 & International Journal of Technology Management & 0 & 2 & 0.000 & 5 \\
\hline- & European Economic Review ${ }^{4}$ & 0 & 0 & $\mathrm{n} / \mathrm{a}$ & 5 \\
\hline
\end{tabular}

Notes

1. Table includes all journals with at least 5 submissions to RAE 2001 and is ordered on aggregate preference ratio.

2. The table only compares journals included therein; it does not summarise all wins/losses for a journal.

3. Win = a paper from the journal was submitted in preference to an available paper from another journal

Loss = a paper from another journal was submitted in preference to one available from the journal.

4. No ranking is possible for European Economic Review as no comparisons are available. 


\begin{tabular}{|c|c|c|c|c|c|c|c|c|c|c|c|}
\hline \multirow[b]{2}{*}{ Rank } & \multirow[b]{2}{*}{ Journal $^{4}$} & \multicolumn{3}{|c|}{$\begin{array}{l}\text { Journal papers submitted } \\
\text { to RAE } 2001 \text { panel }^{1}\end{array}$} & \multicolumn{3}{|c|}{$\begin{array}{l}\text { Publications over period } \\
\text { by research-active staff }{ }^{2}\end{array}$} & \multicolumn{3}{|c|}{$\begin{array}{l}\text { Aggregate submission to } \\
\text { publication ratio (\%) }\end{array}$} & \multirow{2}{*}{$\begin{array}{l}\text { BJP96 } \\
\text { rank }^{3}\end{array}$} \\
\hline & & $A \& F$ & B\&M & Combined & $\mathbf{A} \& \mathbf{F}$ & B\&M & Combined & $\mathbf{A} \& \mathbf{F}$ & B\&M & Combined & \\
\hline 1 & Journal of Financial and Quantitative Analysis & 3 & 2 & 5 & 3 & 2 & 5 & $100 \%$ & $100 \%$ & $100 \%$ & 2 \\
\hline 1 & Journal of Accounting Research & 3 & 2 & 5 & 3 & 2 & 5 & $100 \%$ & $100 \%$ & $100 \%$ & 4 \\
\hline 1 & Accounting and Business Research & 29 & 35 & 64 & 29 & 35 & 64 & $100 \%$ & $100 \%$ & $100 \%$ & 11 \\
\hline 1 & Economic History Review & 1 & 4 & 5 & 1 & 4 & 5 & $100 \%$ & $100 \%$ & $100 \%$ & $\mathrm{nr}$ \\
\hline 1 & European Economic Review & 1 & 4 & 5 & 1 & 4 & 5 & $100 \%$ & $100 \%$ & $100 \%$ & $\mathrm{nr}$ \\
\hline 1 & Journal of Financial Economics & 0 & 6 & 6 & 0 & 6 & 6 & na & $100 \%$ & $100 \%$ & $\mathrm{nr}$ \\
\hline 1 & Journal of the Operational Research Society & 1 & 8 & 9 & 1 & 8 & 9 & $100 \%$ & $100 \%$ & $100 \%$ & $\mathrm{nr}$ \\
\hline 8 & Journal of Finance & 5 & 13 & 18 & 5 & 14 & 19 & $100 \%$ & $93 \%$ & $95 \%$ & 1 \\
\hline 9 & Journal of Futures Markets & 5 & 12 & 17 & 6 & 13 & 19 & $83 \%$ & $92 \%$ & $89 \%$ & $\mathrm{nr}$ \\
\hline 10 & Journal of Banking and Finance & 6 & 26 & 32 & 8 & 28 & 36 & $75 \%$ & $93 \%$ & $89 \%$ & $\mathrm{nr}$ \\
\hline 10 & Journal of Empirical Finance & 5 & 3 & 8 & 6 & 3 & 9 & $83 \%$ & $100 \%$ & $89 \%$ & $\mathrm{nr}$ \\
\hline 12 & Academy of Management Journal & 2 & 5 & 7 & 2 & 6 & 8 & $100 \%$ & $83 \%$ & $88 \%$ & $\mathrm{nr}$ \\
\hline 13 & Economic Journal & 4 & 2 & 6 & 5 & 2 & 7 & $80 \%$ & $100 \%$ & $86 \%$ & $\mathrm{nr}$ \\
\hline 13 & Human Relations & 2 & 4 & 6 & 2 & 5 & 7 & $100 \%$ & $80 \%$ & $86 \%$ & $\mathrm{nr}$ \\
\hline 13 & International Journal of Information Management & 0 & 6 & 6 & 0 & 7 & 7 & na & $86 \%$ & $86 \%$ & $\mathrm{nr}$ \\
\hline 13 & Review of Financial Studies & 3 & 9 & 12 & 3 & 11 & 14 & $100 \%$ & $82 \%$ & $86 \%$ & $\mathrm{nr}$ \\
\hline 17 & European Finance Review & 1 & 4 & 5 & 2 & 4 & 6 & $50 \%$ & $100 \%$ & $83 \%$ & $\mathrm{nr}$ \\
\hline 17 & Review of Economic Studies & 5 & 0 & 5 & 6 & 0 & 6 & $83 \%$ & na & $83 \%$ & $\mathrm{nr}$ \\
\hline 19 & Journal of Business Finance and Accounting & 66 & 56 & 122 & 73 & 77 & 150 & $90 \%$ & $73 \%$ & $81 \%$ & 10 \\
\hline 20 & Accounting Organizations and Society & 24 & 17 & 41 & 28 & 24 & 52 & $86 \%$ & $71 \%$ & $79 \%$ & 6 \\
\hline 21 & Abacus & 3 & 4 & 7 & 4 & 5 & 9 & $75 \%$ & $80 \%$ & $78 \%$ & 21 \\
\hline 21 & Accounting Historians Journal & 6 & 1 & 7 & 6 & 3 & 9 & $100 \%$ & $33 \%$ & $78 \%$ & 27 \\
\hline 21 & Manchester School of Economic and Social Studies & 9 & 5 & 14 & 10 & 8 & 18 & $90 \%$ & $63 \%$ & $78 \%$ & $\mathrm{nr}$ \\
\hline 24 & Journal of International Money and Finance & 4 & 9 & 13 & 6 & 11 & 17 & $67 \%$ & $82 \%$ & $76 \%$ & $\mathrm{nr}$ \\
\hline 25 & Organization & 2 & 7 & 9 & 5 & 7 & 12 & $40 \%$ & $100 \%$ & $75 \%$ & $\mathrm{nr}$ \\
\hline 26 & Accounting Auditing and Accountability Journal & 31 & 27 & 58 & 41 & 40 & 81 & $76 \%$ & $68 \%$ & $72 \%$ & 26 \\
\hline 27 & Managerial Finance & 2 & 3 & 5 & 4 & 3 & 7 & $50 \%$ & $100 \%$ & $71 \%$ & 43 \\
\hline 27 & European Journal of Operational Research & 3 & 2 & 5 & 4 & 3 & 7 & $75 \%$ & $67 \%$ & $71 \%$ & $\mathrm{nr}$ \\
\hline 27 & International Journal of Technology Management & 2 & 3 & 5 & 3 & 4 & 7 & $67 \%$ & $75 \%$ & $71 \%$ & $\mathrm{nr}$ \\
\hline 30 & Management Accounting Research & 23 & 24 & 47 & 35 & 31 & 66 & $66 \%$ & $77 \%$ & $71 \%$ & 18 \\
\hline 31 & British Accounting Review & 24 & 32 & 56 & 37 & 43 & 80 & $65 \%$ & $74 \%$ & $70 \%$ & 28 \\
\hline 31 & Applied Economics & 0 & 7 & 7 & 0 & 10 & 10 & na & $70 \%$ & $70 \%$ & $\mathrm{nr}$ \\
\hline 33 & International Journal of Accounting & 1 & 10 & 11 & 3 & 13 & 16 & $33 \%$ & $77 \%$ & $69 \%$ & 30 \\
\hline 34 & Financial Accountability and Management & 8 & 24 & 32 & 15 & 33 & 48 & $53 \%$ & $73 \%$ & $67 \%$ & 17 \\
\hline 34 & Business History & 0 & 6 & 6 & 2 & 7 & 9 & na & $86 \%$ & $67 \%$ & 22 \\
\hline 34 & International Journal of Finance and Economics & 7 & 1 & 8 & 9 & 3 & 12 & $78 \%$ & $33 \%$ & $67 \%$ & $\mathrm{nr}$ \\
\hline 34 & Journal of Economic Dynamics and Control & 2 & 4 & 6 & 3 & 6 & 9 & $67 \%$ & $67 \%$ & $67 \%$ & $\mathrm{nr}$ \\
\hline 34 & Journal of Management Studies & 0 & 6 & 6 & 1 & 8 & 9 & na & $75 \%$ & $67 \%$ & $\mathrm{nr}$ \\
\hline 39 & Journal of Int'l Accounting, Auditing and Taxation & 4 & 1 & 5 & 5 & 3 & 8 & $80 \%$ & $33 \%$ & $63 \%$ & 36 \\
\hline 40 & British Journal of Management & 2 & 11 & 13 & 3 & 18 & 21 & $67 \%$ & $61 \%$ & $62 \%$ & $\mathrm{nr}$ \\
\hline 41 & $\mathrm{~J}$ of Int'l Financial Management and Accounting & 6 & 2 & 8 & 9 & 4 & 13 & $67 \%$ & $50 \%$ & $62 \%$ & 9 \\
\hline 42 & Accounting Business and Financial History & 13 & 9 & 22 & 19 & 17 & 36 & $68 \%$ & $53 \%$ & $61 \%$ & 29 \\
\hline 43 & Accounting Education & 11 & 12 & 23 & 16 & 22 & 38 & $69 \%$ & $55 \%$ & $61 \%$ & 44 \\
\hline 44 & Long Range Planning & 0 & 6 & 6 & 1 & 9 & 10 & na & $67 \%$ & $60 \%$ & $\mathrm{nr}$ \\
\hline 45 & European Financial Management & 6 & 11 & 17 & 14 & 15 & 29 & $43 \%$ & $73 \%$ & $59 \%$ & $\mathrm{nr}$ \\
\hline 46 & Critical Perspectives on Accounting & 21 & 27 & 48 & 35 & 47 & 82 & $60 \%$ & $57 \%$ & $59 \%$ & 16 \\
\hline 47 & International Journal of Auditing & 7 & 8 & 15 & 12 & 14 & 26 & $58 \%$ & $57 \%$ & $58 \%$ & $\mathrm{nr}$ \\
\hline 48 & European Accounting Review & 18 & 18 & 36 & 30 & 34 & 64 & $60 \%$ & $53 \%$ & $56 \%$ & 38 \\
\hline 49 & Organization Studies & 1 & 4 & 5 & 3 & 6 & 9 & $33 \%$ & $67 \%$ & $56 \%$ & $\mathrm{nr}$ \\
\hline 50 & Applied Financial Economics & 7 & 15 & 22 & 17 & 23 & 40 & $41 \%$ & $65 \%$ & $55 \%$ & $\mathrm{nr}$ \\
\hline 50 & European Journal of Finance & 2 & 20 & 22 & 9 & 31 & 40 & $22 \%$ & $65 \%$ & $55 \%$ & $\mathrm{nr}$ \\
\hline 52 & British Tax Review & 7 & 2 & 9 & 7 & 10 & 17 & $100 \%$ & $20 \%$ & $53 \%$ & 39 \\
\hline 53 & Journal of Financial Regulation and Compliance & 2 & 9 & 11 & 6 & 15 & 21 & $33 \%$ & $60 \%$ & $52 \%$ & $\mathrm{nr}$ \\
\hline 54 & Economics Letters & 3 & 3 & 6 & 5 & 7 & 12 & $60 \%$ & $43 \%$ & $50 \%$ & $\mathrm{nr}$ \\
\hline 54 & European Business Review & 3 & 3 & 6 & 5 & 7 & 12 & $60 \%$ & $43 \%$ & $50 \%$ & $\mathrm{nr}$ \\
\hline 56 & Corporate Governance: An Int'l Review & 3 & 10 & 13 & 5 & 22 & 27 & $60 \%$ & $45 \%$ & $48 \%$ & $\mathrm{nr}$ \\
\hline 57 & Accounting Forum & 8 & 2 & 10 & 16 & 5 & 21 & $50 \%$ & $40 \%$ & $48 \%$ & $\mathrm{nr}$ \\
\hline 57 & Accounting History & 4 & 6 & 10 & 11 & 10 & 21 & $36 \%$ & $60 \%$ & $48 \%$ & $\mathrm{nr}$ \\
\hline 59 & Omega: Int'l Journal of Management Science & 1 & 4 & 5 & 1 & 10 & 11 & $100 \%$ & $40 \%$ & $45 \%$ & $\mathrm{nr}$ \\
\hline 60 & Journal of Applied Accounting Research & 4 & 10 & 14 & 8 & 25 & 33 & $50 \%$ & $40 \%$ & $42 \%$ & $\mathrm{nr}$ \\
\hline 61 & Irish Accounting Review & 1 & 4 & 5 & 6 & 7 & 13 & $17 \%$ & $57 \%$ & $38 \%$ & $\mathrm{nr}$ \\
\hline 62 & Managerial Auditing Journal & 0 & 7 & 7 & 1 & 18 & 19 & na & $39 \%$ & $37 \%$ & $\mathrm{nr}$ \\
\hline 63 & Public Money and Management & 0 & 8 & 8 & 3 & 21 & 24 & na & $38 \%$ & $33 \%$ & 42 \\
\hline
\end{tabular}


Table 5: Ranking based on metric 3: aggregate submission to publication ratio (continued)

Panel B: Journals with less than five submissions to RAE 2001, but included in Brinn et al. (1996) ranking

Rank Journal ${ }^{5}$

Journal of Accounting and Economics

Contemporary Accounting Research

Journal of Accounting and Public Policy

Journal of Accounting, Auditing and Finance

Journal of Management Accounting Research

Auditing: A Journal of Practice and Theory

Financial Analysts Journal

Advances in Public Interest Accounting

Journal of Accounting Education

Advances in International Accounting

Accounting Horizons

Issues in Accounting Education

Australian Accounting Review

Research in Accounting in Emerging Economies

Journal of Cost Management

Pacific Accounting Review

\section{Journal papers submitted \\ to RAE 2001 panel $^{1}$}

\section{A\&F B\&M Combined}

Publications over period by research-active staff ${ }^{2}$

Aggregate submission to

publication ratio (\%)

$\begin{array}{ccccccc}\text { A\&F } & \text { B\&M } & \text { Combined } & \text { A\&F } & \text { B\&M } & \text { Combined } & \text { rank } \\ 1 & 1 & 2 & 100 \% & 100 \% & 100 \% & 3 \\ 1 & 2 & 3 & 100 \% & 100 \% & 100 \% & 7 \\ 2 & 2 & 4 & 100 \% & 100 \% & 100 \% & 8 \\ 0 & 1 & 1 & \text { na } & 100 \% & 100 \% & 12 \\ 1 & 1 & 2 & 100 \% & 100 \% & 100 \% & 14 \\ 0 & 1 & 1 & \text { na } & 100 \% & 100 \% & 15 \\ 3 & 1 & 4 & 100 \% & 100 \% & 100 \% & 19 \\ 2 & 0 & 2 & 100 \% & \text { na } & 100 \% & 24 \\ 3 & 0 & 3 & 100 \% & \text { na } & 100 \% & 33 \\ 3 & 1 & 4 & 67 \% & 100 \% & 75 \% & 35 \\ 0 & 3 & 3 & \text { na } & 67 \% & 67 \% & 32 \\ 0 & 6 & 6 & \text { na } & 67 \% & 67 \% & 34 \\ 1 & 1 & 2 & 100 \% & \text { na } & 50 \% & 31 \\ 2 & 7 & 9 & 50 \% & 14 \% & 22 \% & 37 \\ 3 & 2 & 5 & \text { na } & 50 \% & 20 \% & 25 \\ 6 & 6 & 12 & 17 \% & \text { na } & 8 \% & 40\end{array}$

Notes

1. Number of papers from journal submitted to RAE 2001.

2. Number of publications in journal by research-active staff from accounting and finance community over period 1996-2000 inclusive

Data sourced from BAR Research Register database and adjusted for any RAE2001 submitted papers omitted therefrom (see text for details).

3. The ranking of the journal in the UK perception study by Brinn, Jones and Pendlebury (1996); $\mathrm{nr}=$ not included in survey for ranking.

4. Journals are ordered on total RAE submission/publication aggregate ratio (\%); within tied ratios, based on BJP96 rank, then alphabetically. 
Table 6: Ranking based on metric 4: Weighted average RAE grade (RAE metric)

\begin{tabular}{|c|c|c|c|c|c|c|c|c|c|c|}
\hline \multirow[b]{2}{*}{ Journal $^{1}$} & \multicolumn{3}{|c|}{ A\&F panel } & \multicolumn{3}{|c|}{ B\&M panel } & \multicolumn{4}{|c|}{ Overall } \\
\hline & Mean $^{2}$ & no subs & Rank $^{3}$ & Mean $^{2}$ & no subs & Rank $^{3}$ & Mean $^{2}$ & Median & no subs & Rank \\
\hline Journal of Accounting Research & 7.00 & 3 & 1 & 7.00 & 2 & 1 & 7.00 & 7 & 5 & 1 \\
\hline Review of Economic Studies & 7.00 & 5 & 1 & & 0 & $\mathrm{nr}$ & 7.00 & 7 & 5 & 1 \\
\hline Review of Financial Studies & 7.00 & 3 & 1 & 7.00 & 9 & 1 & 7.00 & 7 & 12 & 1 \\
\hline Journal of Financial Economics & & 0 & $\mathrm{nr}$ & 6.67 & 6 & 4 & 6.67 & 7 & 6 & 4 \\
\hline Journal of Finance & 6.60 & 5 & 7 & 6.54 & 13 & 5 & 6.56 & 7 & 18 & 5 \\
\hline Economic Journal & 6.50 & 4 & 10 & 6.50 & 2 & 6 & 6.50 & 6.5 & 6 & 6 \\
\hline Accounting Historians Journal & 6.33 & 6 & 13 & 7.00 & 1 & 1 & 6.43 & 6 & 7 & 7 \\
\hline European Economic Review & 7.00 & 1 & 1 & 6.25 & 4 & 9 & 6.40 & 6 & 5 & 8 \\
\hline European Finance Review & 6.00 & 1 & 20 & 6.50 & 4 & 6 & 6.40 & 7 & 5 & 8 \\
\hline Journal of Empirical Finance & 6.60 & 5 & 7 & 6.00 & 3 & 13 & 6.38 & 7 & 8 & 10 \\
\hline Business History & & 0 & $\mathrm{nr}$ & 6.33 & 6 & 8 & 6.33 & 6 & 6 & 11 \\
\hline Accounting Organizations and Society & 6.50 & 24 & 10 & 6.00 & 17 & 13 & 6.29 & 6 & 41 & 12 \\
\hline Economic History Review & 6.00 & 1 & 20 & 6.25 & 4 & 9 & 6.20 & 6 & 5 & 13 \\
\hline Journal of Financial and Quantitative Analysis & 6.67 & 3 & 5 & 5.50 & 2 & 26 & 6.20 & 7 & 5 & 13 \\
\hline Journal of Economic Dynamics and Control & 6.00 & 2 & 20 & 6.25 & 4 & 9 & 6.17 & 6 & 6 & 15 \\
\hline Academy of Management Journal & 6.00 & 2 & 20 & 6.20 & 5 & 12 & 6.14 & 6 & 7 & 16 \\
\hline International Journal of Finance and Economics & 6.14 & 7 & 18 & 6.00 & 1 & 13 & 6.13 & 6 & 8 & 17 \\
\hline Accounting Business and Financial History & 6.31 & 13 & 14 & 5.78 & 9 & 21 & 6.09 & 6 & 22 & 18 \\
\hline Economics Letters & 6.00 & 3 & 20 & 6.00 & 3 & 13 & 6.00 & 6 & 6 & 19 \\
\hline European Financial Management & 6.17 & 6 & 17 & 5.91 & 11 & 19 & 6.00 & 6 & 17 & 19 \\
\hline Human Relations & 6.00 & 2 & 20 & 6.00 & 4 & 13 & 6.00 & 6 & 6 & 19 \\
\hline Journal of International Money and Finance & 6.50 & 4 & 10 & 5.78 & 9 & 21 & 6.00 & 6 & 13 & 19 \\
\hline Organization & 6.00 & 2 & 20 & 6.00 & 7 & 13 & 6.00 & 6 & 9 & 19 \\
\hline Accounting and Business Research & 6.24 & 29 & 16 & 5.77 & 35 & 23 & 5.98 & 6 & 64 & 24 \\
\hline Journal of Banking and Finance & 6.00 & 6 & 20 & 5.88 & 26 & 20 & 5.91 & 6 & 32 & 25 \\
\hline Journal of Business Finance and Accounting & 6.02 & 66 & 19 & 5.68 & 56 & 24 & 5.86 & 6 & 122 & 26 \\
\hline $\mathrm{J}$ of International Financial Mgt and Accounting & 6.00 & 6 & 20 & 5.00 & 2 & 40 & 5.75 & 6 & 8 & 27 \\
\hline Accounting History & 6.25 & 4 & 15 & 5.33 & 6 & 30 & 5.70 & 6 & 10 & 28 \\
\hline Management Accounting Research & 5.83 & 23 & 38 & 5.54 & 24 & 25 & 5.68 & 6 & 47 & 29 \\
\hline Journal of Futures Markets & 6.60 & 5 & 7 & 5.25 & 12 & 33 & 5.65 & 6 & 17 & 30 \\
\hline Critical Perspectives on Accounting & 6.00 & 21 & 20 & 5.33 & 27 & 30 & 5.63 & 6 & 48 & 31 \\
\hline J of Int'l Accounting, Auditing and Taxation & 5.75 & 4 & 40 & 5.00 & 1 & 40 & 5.60 & 6 & 5 & 32 \\
\hline Accounting Auditing and Accountability Journal & 5.97 & 31 & 37 & 5.15 & 27 & 39 & 5.59 & 6 & 58 & 33 \\
\hline European Accounting Review & 6.00 & 18 & 20 & 5.17 & 18 & 36 & 5.58 & 6 & 36 & 34 \\
\hline Manchester School of Economic and Social Studit & 5.78 & 9 & 39 & 5.20 & 5 & 35 & 5.57 & 6 & 14 & 35 \\
\hline British Tax Review & 5.57 & 7 & 46 & 5.50 & 2 & 26 & 5.56 & 6 & 9 & 36 \\
\hline Abacus & 6.00 & 3 & 20 & 5.00 & 4 & 40 & 5.43 & 6 & 7 & 37 \\
\hline Omega: International J of Management Science & 6.00 & 1 & 20 & 5.25 & 4 & 33 & 5.40 & 5 & 5 & 38 \\
\hline Public Money and Management & & 0 & $\mathrm{nr}$ & 5.38 & 8 & 28 & 5.38 & 6 & 8 & 39 \\
\hline International Journal of Auditing & 5.71 & 7 & 44 & 5.00 & 8 & 40 & 5.33 & 5 & 15 & 40 \\
\hline Accounting Forum & 5.75 & 8 & 40 & 3.50 & 2 & 61 & 5.30 & 5.5 & 10 & 41 \\
\hline British Accounting Review & 5.75 & 24 & 40 & 4.94 & 32 & 46 & 5.29 & 5 & 56 & 42 \\
\hline European Journal of Finance & 4.50 & 2 & 50 & 5.35 & 20 & 29 & 5.27 & 5 & 22 & 43 \\
\hline Organization Studies & 6.00 & 1 & 20 & 5.00 & 4 & 40 & 5.20 & 5 & 5 & 44 \\
\hline Journal of Management Studies & & 0 & $\mathrm{nr}$ & 5.17 & 6 & 36 & 5.17 & 5 & 6 & 45 \\
\hline Long Range Planning & & 0 & $\mathrm{nr}$ & 5.17 & 6 & 36 & 5.17 & 5.5 & 6 & 45 \\
\hline Financial Accountability and Management & 5.38 & 8 & 48 & 5.00 & 24 & 40 & 5.09 & 5 & 32 & 47 \\
\hline International Journal of Accounting & 3.00 & 1 & 54 & 5.30 & 10 & 32 & 5.09 & 5 & 11 & 47 \\
\hline European Journal of Operational Research & 6.67 & 3 & 5 & 2.50 & 2 & 62 & 5.00 & 6 & 5 & 49 \\
\hline Journal of Financial Regulation and Compliance & 6.00 & 2 & 20 & 4.78 & 9 & 48 & 5.00 & 5 & 11 & 49 \\
\hline Applied Financial Economics & 5.29 & 7 & 49 & 4.80 & 15 & 47 & 4.95 & 5 & 22 & 51 \\
\hline Journal of the Operational Research Society & 6.00 & 1 & 20 & 4.75 & 8 & 49 & 4.89 & 5 & 9 & 52 \\
\hline Accounting Education & 5.73 & 11 & 43 & 4.08 & 12 & 57 & 4.87 & 5 & 23 & 53 \\
\hline British Journal of Management & 5.50 & 2 & 47 & 4.73 & 11 & 50 & 4.85 & 5 & 13 & 54 \\
\hline Managerial Auditing Journal & & 0 & $\mathrm{nr}$ & 4.71 & 7 & 51 & 4.71 & 4 & 7 & 55 \\
\hline Irish Accounting Review & 6.00 & 1 & 20 & 4.25 & 4 & 55 & 4.60 & 5 & 5 & 56 \\
\hline International Journal of Technology Management & 4.50 & 2 & 50 & 4.33 & 3 & 53 & 4.40 & 4 & 5 & 57 \\
\hline Corporate Governance: An International Review & 5.67 & 3 & 45 & 4.00 & 10 & 58 & 4.38 & 4 & 13 & 58 \\
\hline Journal of Applied Accounting Research & 4.00 & 4 & 52 & 4.50 & 10 & 52 & 4.36 & 4.5 & 14 & 59 \\
\hline International Journal of Information Management & & 0 & $\mathrm{nr}$ & 4.17 & 6 & 56 & 4.17 & 3.5 & 6 & 60 \\
\hline Managerial Finance & 4.00 & 2 & 52 & 4.00 & 3 & 58 & 4.00 & 3 & 5 & 61 \\
\hline Applied Economics & & 0 & $\mathrm{nr}$ & 3.86 & 7 & 60 & 3.86 & 3 & 7 & 62 \\
\hline European Business Review & 3.00 & 3 & 54 & 4.33 & 3 & 53 & 3.67 & 3.5 & 6 & 63 \\
\hline
\end{tabular}

Notes : 1 . Table is ordered on overall mean RAE metric, then within tied means, alphabetically.

Boxes mark the mid-point boundaries between grades 7 (>6.5), 6 (5.5-6.5), 5 (4.5-5.5), and 4 (3.5-4.5).

2. Mean RAE metric is the weighted average RAE 2001 grade of UoAs submitting papers from each journal.

3. nr means no ranking possible as there were no submissions to the $A \& F(B \& M)$ panel in RAE 2001. 
Table 7: Summary of rankings from present study and comparison with recent perception survey studies

Panel A: Accounting Journals

\begin{tabular}{|c|c|c|c|c|c|c|c|c|c|c|c|c|c|}
\hline \multirow[b]{3}{*}{ Journal $^{1}$} & \multirow[b]{3}{*}{$\begin{array}{l}\text { No of RAE } \\
\text { submissions }\end{array}$} & \multicolumn{4}{|c|}{ Ranking based on metric number } & & \multirow[b]{3}{*}{$\begin{array}{l}\text { Acc'g } \\
\text { rank }\end{array}$} & \multicolumn{6}{|c|}{ Perception surveys } \\
\hline & & \multirow{2}{*}{\begin{tabular}{|c|}
1 \\
indiv \\
pairs $^{2}$
\end{tabular}} & \multirow{2}{*}{$\begin{array}{c}2 \\
\text { agg pref } \\
\text { ratio }^{3}\end{array}$} & \multirow{2}{*}{$\begin{array}{c}\text { 3 } \\
\text { agg sub } \\
/ \text { pub }^{4}\end{array}$} & \multirow{2}{*}{$\begin{array}{c}4 \\
\text { RAE } \\
\text { metric }^{5}\end{array}$} & \multirow[b]{2}{*}{$\begin{array}{c}\text { Overall } \\
\text { rank }^{6}\end{array}$} & & \multicolumn{4}{|c|}{ Accounting } & \multicolumn{2}{|c|}{ Finance } \\
\hline & & & & & & & & bjp96 $^{7}$ & \begin{tabular}{|c|}
$\mathrm{UK}$ \\
$1105^{8}$ \\
\end{tabular} & \begin{tabular}{|l|} 
EUR \\
bt039
\end{tabular} & $\begin{array}{c}\text { US } \\
\text { bt03 }^{9}\end{array}$ & \begin{tabular}{|c|} 
EUR \\
ott03 $^{10}$
\end{tabular} & $\begin{array}{c}\text { US } \\
\text { otto3 }^{10}\end{array}$ \\
\hline Journal of Accounting Research & 5 & & 1 & 1 & 1 & 1 & 1 & 4 & 3 & 3 & 2 & $\mathrm{nr}$ & 26 \\
\hline Accounting and Business Research & 64 & 4 & 15 & 1 & 24 & 9 & 2 & 11 & 7 & 6 & 18 & & \\
\hline Accounting Organizations and Society & 41 & 1 & 10 & 20 & 12 & 10 & 3 & 6 & 1 & 2 & 5 & & \\
\hline Journal of Business Finance and Accounting & 122 & 6 & 17 & 19 & 26 & 20 & 4 & 10 & 8 & 15 & 22 & 20 & 40 \\
\hline Accounting Historians Journal & 7 & & 43 & 21 & 7 & 21 & 5 & 27 & & 36 & 32 & & \\
\hline Accounting Auditing and Accountability $\mathrm{J}$ & 58 & 5 & 16 & 26 & 33 & 23 & 6 & 26 & 9 & 7 & 26 & & \\
\hline Abacus & 7 & & 20 & 21 & 37 & 27 & 7 & 21 & 19 & 11 & 15 & & \\
\hline Management Accounting Research & 47 & 8 & 29 & 30 & 29 & 29 & 8 & 18 & 11 & 10 & 29 & & \\
\hline J of Int'l Accounting, Auditing and Taxation & 5 & & 18 & 39 & 32 & 30 & 9 & 36 & & 37 & 39 & & \\
\hline J of Int'l Financial Mgt and Accounting & 8 & & 26 & 41 & 27 & 31 & 10 & 9 & 18 & $n r$ & $n r$ & $n r$ & $n r$ \\
\hline Accounting Business and Financial History & 22 & 9 & 39 & 42 & 18 & 33 & 11 & 29 & 16 & 33 & $\mathrm{nr}$ & & \\
\hline International Journal of Accounting & 11 & & 20 & 33 & 47 & 34 & 12 & 30 & 29 & 23 & 30 & & \\
\hline Critical Perspectives on Accounting & 48 & 7 & 27 & 46 & 31 & 37 & 13 & 16 & 13 & 12 & 23 & & \\
\hline British Accounting Review & 56 & 12 & 34 & 31 & 42 & 39 & 14 & 28 & 24 & 13 & 27 & & \\
\hline Financial Accountability and Management & 32 & 10 & 30 & 34 & 47 & 40 & 15 & 17 & 20 & 28 & $\mathrm{nr}$ & & \\
\hline European Accounting Review & 36 & 14 & 36 & 48 & 34 & 41 & 16 & 38 & 23 & 4 & 28 & & \\
\hline International Journal of Auditing & 15 & 13 & 38 & 47 & 40 & 44 & 17 & & & $\mathrm{nr}$ & $\mathrm{nr}$ & & \\
\hline Accounting History & 10 & & 42 & 57 & 28 & 45 & 18 & & & 31 & $\mathrm{nr}$ & & \\
\hline British Tax Review & 9 & & 53 & 52 & 36 & 48 & 19 & 39 & & & & & \\
\hline Accounting Education & 23 & 16 & 55 & 43 & 53 & 55 & 20 & 44 & 28 & 24 & 36 & & \\
\hline $\mathrm{J}$ of Financial Regulation and Compliance & 11 & & 51 & 53 & 49 & 56 & 21 & & & & & & \\
\hline Accounting Forum & 10 & & 60 & 57 & 41 & 57 & 22 & & 30 & 35 & $\mathrm{nr}$ & & \\
\hline Corporate Governance: An Int'l Review & 13 & & 45 & 56 & 58 & 58 & 23 & & & & & & \\
\hline Managerial Auditing Journal & 7 & & 49 & 62 & 55 & 60 & 24 & & & & & & \\
\hline Journal of Applied Accounting Research & 14 & 18 & 55 & 60 & 59 & 61 & 25 & & & & & & \\
\hline Irish Accounting Review & 5 & & 58 & 61 & 56 & 62 & 26 & & & & & & \\
\hline
\end{tabular}

Notes 1. Journals in italics are classified as both accounting and finance and, therefore, are shown in both panels A and B.

$\begin{array}{ll}\text { 2. Source: Table } 3 \text { present study; } 18 \text { journals ranked } & 3 \text {. Source: Table } 4 \text { present study; } 63 \text { journals ranked }\end{array}$

$\begin{array}{ll}\text { 4. Source: Table } 5 \text { present study; } 63 \text { journals ranked } & \text { 5. Source: Table } 6 \text { present study; } 63 \text { journals ranked }\end{array}$

6. The overall ranking is based on the simple mean of the ranks from the three aggregate metrics (metrics 2 - 4 above).

7. Source: Brinn, Jones and Pendlebury (1996); 44 journals ranked $\quad 8$. Source: Lowe and Locke (2005); 30 journals ranked

9. Source: Ballas and Theoharakis (2003); 40 journals ranked; US (EUR) $=$ US (European) rankings [ $\mathrm{nr}=$ not ranked within the top 40]

10. Source: Oltheten et al. (2003); 40 journals ranked; US (EUR) = US (European) rankings [ $\mathrm{nr}=$ not ranked within the top 40] 


\section{Table 7 (continued): Summary of rankings from present study and comparison with recent perception survey studies}

Panel B: Finance Journals

\begin{tabular}{|c|c|c|c|c|c|c|c|}
\hline \multirow[b]{3}{*}{ Journal $^{1}$} & & \multicolumn{4}{|c|}{ Ranking based on metric number } & \multirow[b]{3}{*}{$\begin{array}{c}\text { Overall } \\
\text { rank }^{6}\end{array}$} & \multirow[b]{3}{*}{$\begin{array}{c}\text { Finance } \\
\text { rank }\end{array}$} \\
\hline & & 1 & 2 & 3 & 4 & & \\
\hline & $\begin{array}{l}\text { No of RAE } \\
\text { submissions }\end{array}$ & $\begin{array}{l}\text { indiv } \\
\text { pairs }^{2}\end{array}$ & $\begin{array}{c}\text { agg pref } \\
\text { ratio }^{3}\end{array}$ & $\begin{array}{c}\text { agg sub } \\
/ \text { pub }^{4}\end{array}$ & $\begin{array}{c}\text { RAE } \\
\text { metric }^{5}\end{array}$ & & \\
\hline Journal of Financial Economics & 6 & & 1 & $\mathbf{1}$ & 4 & 2 & 1 \\
\hline Journal of Financial and Quantitative Analysis & 5 & & 1 & $\mathbf{1}$ & 13 & 4 & 2 \\
\hline Journal of Finance & 18 & & 8 & 8 & 5 & 6 & 3 \\
\hline Review of Financial Studies & 12 & & 31 & 13 & 1 & 11 & 4 \\
\hline Journal of Banking and Finance & 32 & 2 & 11 & 10 & 25 & 12 & 5 \\
\hline Journal of Empirical Finance & 8 & & 28 & 10 & 10 & 14 & 6 \\
\hline European Finance Review & 5 & & 24 & 17 & 8 & 15 & 7 \\
\hline Journal of International Money and Finance & 13 & & 9 & 24 & 19 & 16 & 8 \\
\hline Journal of Futures Markets & 17 & 3 & 13 & 9 & 30 & 16 & 8 \\
\hline Journal of Business Finance and Accounting & 122 & 6 & 17 & 19 & 26 & 20 & 10 \\
\hline International J of Finance and Economics & 8 & & 22 & 34 & 17 & 22 & 11 \\
\hline J of Int'l Financial Mgt and Accounting & 8 & & 26 & 41 & 27 & 31 & 12 \\
\hline European Financial Management & 17 & 11 & 41 & 45 & 19 & 38 & 13 \\
\hline Managerial Finance & 5 & & 44 & 27 & 61 & 46 & 14 \\
\hline European Journal of Finance & 22 & 17 & 52 & $\mathbf{5 0}$ & 43 & 51 & 15 \\
\hline Applied Financial Economics & 22 & 15 & 46 & $\mathbf{5 0}$ & 51 & 54 & 16 \\
\hline
\end{tabular}

\begin{tabular}{|c|c|c|c|c|c|}
\hline \multicolumn{5}{|c|}{ Perception surveys } \\
\hline \multicolumn{5}{|c|}{ Accounting } & \multicolumn{2}{c|}{ Finance } \\
\hline & $\begin{array}{c}\text { UK } \\
\text { bjp96 }^{\mathbf{7}}\end{array}$ & $\begin{array}{c}\text { EUR } \\
\mathbf{l 1 0 5}^{\mathbf{8}}\end{array}$ & $\begin{array}{c}\text { US } \\
\mathbf{b t 0 3}^{\mathbf{9}}\end{array}$ & $\begin{array}{c}\mathbf{E U R}_{\mathbf{6}} \mathbf{b 3}^{\mathbf{9}} \\
\mathbf{o t t 0 3}^{\mathbf{1 0}}\end{array}$ & $\begin{array}{c}\text { US } \\
\mathbf{o t t 0 3}^{\mathbf{1 0}}\end{array}$ \\
\hline & & & & 2 & 2 \\
\hline 2 & & & & 4 & 4 \\
\hline 1 & & & & 1 & 1 \\
\hline & & & & 3 & 3 \\
\hline & & & & 5 & 10 \\
\hline & & & & 10 & 19 \\
\hline & & & & 12 & 38 \\
\hline & & & & 21 & 32 \\
\hline & & & & 27 & 28 \\
\hline 10 & 8 & 15 & 22 & 20 & 40 \\
\hline & & & & & \\
\hline 9 & 18 & $n r$ & $n r$ & $n r$ & $n r$ \\
\hline & & & & 19 & $\mathrm{nr}$ \\
\hline 43 & & & & & \\
\hline & & & & 24 & $\mathrm{nr}$ \\
\hline & & & & 32 & $\mathrm{nr}$ \\
\hline
\end{tabular}

Notes 1. Journals in italics are classified as both accounting and finance and, therefore, are shown in both panels A and B
2. Source: Table 3 present study; 18 journals ranked
3. Source: Table 4 present study; 63 journals ranked
4. Source: Table 5 present study; 63 journals ranked
5. Source: Table 6 present study; 63 journals ranked
6. The overall ranking is based on the simple mean of the ranks from the three aggregate metrics (metrics $2-4$ above)
7. Source: Brinn, Jones and Pendlebury (1996); 44 journals ranked $\quad 8$. Source: Lowe and Locke (2005); 30 journals ranked
9. Source: Ballas and Theoharakis (2003); 40 journals ranked; US (EUR) $=$ US (European) rankings [nr $=$ not ranked within the top 40]
10. Source: Oltheten et al. (2003); 40 journals ranked; US (EUR) $=$ US (European) rankings [ $\mathrm{nr}=$ not ranked within the top 40] 


\section{Table 7 (continued): Summary of rankings from present study and comparison with recent perception survey studies}

Panel C: Non-core Journals

\begin{tabular}{|c|c|c|c|c|c|c|c|}
\hline \multirow[b]{3}{*}{ Journal } & & \multicolumn{4}{|c|}{ Ranking based on metric number } & \multirow[b]{3}{*}{$\begin{array}{c}\text { Overall } \\
\text { rank }^{6}\end{array}$} & \multirow[b]{3}{*}{$\begin{array}{c}\text { Non-core } \\
\text { rank }\end{array}$} \\
\hline & & 1 & 2 & 3 & 4 & & \\
\hline & $\begin{array}{l}\text { No of RAE } \\
\text { submissions }\end{array}$ & $\begin{array}{l}\text { indiv } \\
\text { pairs }^{2}\end{array}$ & $\begin{array}{c}\text { agg pref } \\
\text { ratio }^{3}\end{array}$ & $\begin{array}{l}\text { agg sub } \\
/ \text { pub }^{4}\end{array}$ & $\begin{array}{c}\text { RAE } \\
\text { metric }^{5}\end{array}$ & & \\
\hline European Economic Review & 5 & & $\mathrm{n} / \mathrm{a}$ & 1 & 8 & 3 & 1 \\
\hline Review of Economic Studies & 5 & & 1 & 17 & 1 & 5 & 2 \\
\hline Economic History Review & 5 & & 12 & 1 & 13 & 7 & 3 \\
\hline Academy of Management Journal & 7 & & 1 & 12 & 16 & 8 & 4 \\
\hline Human Relations & 6 & & 14 & 13 & 19 & 12 & 5 \\
\hline Journal of the Operational Research Society & 9 & & 1 & 1 & 52 & 18 & 6 \\
\hline Economic Journal & 6 & & 37 & 13 & 6 & 19 & 7 \\
\hline Manchester School of Econ and Social Studies & 14 & & 19 & 21 & 35 & 23 & 8 \\
\hline Business History & 6 & & 31 & 34 & 11 & 25 & 9 \\
\hline European Journal of Operational Research & 5 & & 1 & 27 & 49 & 26 & 10 \\
\hline Organization & 9 & & 35 & 25 & 19 & 28 & 11 \\
\hline Economics Letters & 6 & & 25 & 54 & 19 & 32 & 12 \\
\hline Journal of Management Studies & 6 & & 23 & 34 & 45 & 35 & 13 \\
\hline Journal of Economic Dynamics and Control & 6 & & 53 & 34 & 15 & 35 & 13 \\
\hline International Journal of Information Mgt & 6 & & 47 & 13 & 60 & 42 & 15 \\
\hline Organization Studies & 5 & & 31 & 49 & 44 & 43 & 16 \\
\hline British Journal of Management & 13 & & 40 & 40 & 54 & 47 & 17 \\
\hline Applied Economics & 7 & & 49 & 31 & 62 & 49 & 18 \\
\hline Omega: International J of Mgt Science & 5 & & 47 & 59 & 38 & $\mathbf{5 0}$ & 19 \\
\hline International Journal of Technology Mgt & 5 & & 62 & 27 & 57 & 52 & 20 \\
\hline Long Range Planning & 6 & & 57 & 44 & 45 & 52 & 20 \\
\hline Public Money and Management & 8 & & 61 & 63 & 39 & 59 & 22 \\
\hline European Business Review & 6 & & 59 & 54 & 63 & 63 & 23 \\
\hline
\end{tabular}

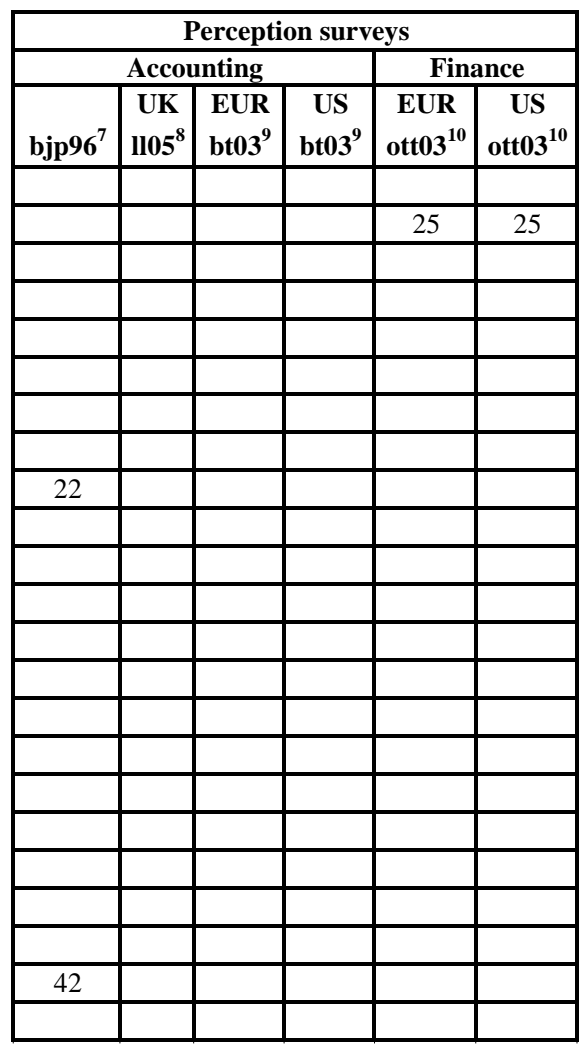

Notes 1. Journals in italics are classified as both accounting and finance and, therefore, are shown in both panels A and B

2. Source: Table 3 present study; 18 journals ranked

3. Source: Table 4 present study; 63 journals ranked

4. Source: Table 5 present study; 63 journals ranked

5. Source: Table 6 present study; 63 journals ranked

6. The overall ranking is based on the simple mean of the ranks from the three aggregate metrics (metrics 2 - 4 above)

7. Source: Brinn, Jones and Pendlebury (1996); 44 journals ranked $\quad$ 8. Source: Lowe and Locke (2005); 30 journals ranked

9. Source: Ballas and Theoharakis (2003); 40 journals ranked; US (EUR) $=$ US (European) rankings [nr $=$ not ranked within the top 40]

10. Source: Oltheten et al. (2003); 40 journals ranked; US (EUR) = US (European) rankings [ $\mathrm{nr}=$ not ranked within the top 40] 
Table 8: Spearman rank correlations between journal rankings in Table 7

\begin{tabular}{|c|c|c|c|c|c|c|c|c|c|c|}
\hline & \multicolumn{5}{|c|}{ Present study } & \multicolumn{5}{|c|}{ Perception surveys } \\
\hline & \multirow[b]{3}{*}{$\begin{array}{c}\text { Overall } \\
\text { rank }^{1}\end{array}$} & \multicolumn{4}{|c|}{ Metric } & \multirow{12}{*}{ bjp96 ${ }^{6}$} & \multirow[b]{3}{*}{$\begin{array}{c}\text { UK } \\
1105^{7}\end{array}$} & \multirow[b]{3}{*}{$\begin{array}{l}\text { EUR } \\
\text { bt03 }^{8}\end{array}$} & \multirow[b]{3}{*}{$\begin{array}{c}\text { US } \\
\text { bt03 }^{8}\end{array}$} & \multirow[b]{3}{*}{$\begin{array}{c}\text { EUR } \\
\operatorname{ott03}^{9}\end{array}$} \\
\hline & & 1 & 2 & 3 & 4 & & & & & \\
\hline & & $\begin{array}{l}\text { indiv } \\
\text { pairs }^{2}\end{array}$ & $\begin{array}{c}\text { agg pref } \\
\text { ratio }^{3}\end{array}$ & $\begin{array}{c}\text { agg sub } \\
/ \text { pub }^{4}\end{array}$ & $\begin{array}{c}\text { RAE } \\
\text { metric }^{5}\end{array}$ & & & & & \\
\hline \multicolumn{10}{|l|}{ Present study } & \\
\hline indiv pairs & $.96 * *$ & & & & & & & & & \\
\hline [Metric 1] & 18 & & & & & & & & & \\
\hline agg pref ratio & $.89 * *$ & $.96 * *$ & & & & & & & & \\
\hline [Metric 2] & 62 & 18 & & & & & & & & \\
\hline agg sub/pub & $.89 * *$ & $.88 * *$ & $.74 * *$ & & & & & & & \\
\hline [Metric 3] & 63 & 18 & 62 & & & & & & & \\
\hline RAE metric & $.82 * *$ & $.77 * *$ & $.56 * *$ & $.56 * *$ & & & & & & \\
\hline [Metric 4] & 63 & 18 & 62 & 63 & & & & & & \\
\hline \multicolumn{11}{|c|}{ Perception surveys } \\
\hline \multirow[t]{2}{*}{ bjp96 (UK) } & $.82 * *$ & $.84 * *$ & $.82 * *$ & $.68 * *$ & $.70 * *$ & & & & & \\
\hline & 23 & 11 & 23 & 23 & 23 & & & & & \\
\hline \multirow[t]{2}{*}{1105 (UK) } & $.89 * *$ & $.97 * *$ & $.78 * *$ & $.73 * *$ & $.86 * *$ & $.79 * *$ & & & & \\
\hline & 16 & 11 & 16 & 16 & 16 & 15 & & & & \\
\hline \multirow[t]{2}{*}{ bt03 (EUR) } & $.47 *$ & .49 & $.64 * *$ & $.50 *$ & .22 & $.52 *$ & $.70 * *$ & & & \\
\hline & 18 & 11 & 18 & 18 & 18 & 16 & 15 & & & \\
\hline \multirow[t]{2}{*}{ bt03 (US) } & $.65 *$ & $.90 * *$ & $.70 * *$ & $.66 * *$ & .46 & $.84 * *$ & $.80 * *$ & $.77 * *$ & & \\
\hline & 14 & 9 & 14 & 14 & 14 & 14 & 12 & 14 & & \\
\hline \multirow[t]{2}{*}{ ott03 (EUR) } & $.70 * *$ & .49 & .37 & $.68 * *$ & $.62 *$ & $1.0 * *$ & . & . & . & \\
\hline & 14 & 6 & 14 & 14 & 14 & 3 & 1 & 1 & 1 & \\
\hline \multirow[t]{2}{*}{$\operatorname{ott03}(\mathrm{US})^{9}$} & $.65 *$ & $1.0 * *$ & .27 & $.63 *$ & .44 & $1.0 * *$ & $1.0 * *$ & $1.0 * *$ & $1.0 * *$ & $.84 * *$ \\
\hline & 12 & 3 & 12 & 12 & 12 & 4 & 2 & 2 & 2 & 11 \\
\hline
\end{tabular}

Notes
1. Source: Table 7 present study; 63 journals ranked
2. Source: Table 3 present study; 18 journals ranked
3. Source: Table 4 present study; 63 journals ranked
4. Source: Table 5 present study; 63 journals ranked
5. Source: Table 6 present study; 63 journals ranked
6. Source: Brinn, Jones and Pendlebury (1996); 44 journals ranked
7. Source: Lowe and Locke (2005); 30 journals ranked
8. Source: Ballas and Theoharakis (2003); 40 journals ranked; US (EUR) = US (European) rankings
9. Source: Oltheten et al. (2003); 40 journals ranked; US (EUR) = US (European) rankings
10. No of journals in the comparison is listed under correlation coefficient; ** (*) significant at the $1 \%(5 \%)$ level $(2$-tailed) 